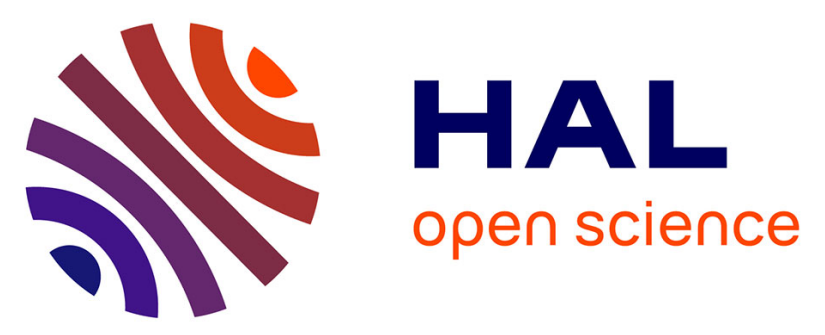

\title{
Geological and thermal conditions before the major Palaeoproterozoic gold-mineralization event at Ashanti, Ghana, as inferred from improved thermal modelling
}

Virginie Harcouët, Laurent Guillou-Frottier, Alain Bonneville, Vincent Bouchot, Jean-Pierre Milesi

\section{To cite this version:}

Virginie Harcouët, Laurent Guillou-Frottier, Alain Bonneville, Vincent Bouchot, Jean-Pierre Milesi. Geological and thermal conditions before the major Palaeoproterozoic gold-mineralization event at Ashanti, Ghana, as inferred from improved thermal modelling. Precambrian Research, 2007, 154 (1-2), pp.71-87. 10.1016/j.precamres.2006.11.014 . hal-00534079

\author{
HAL Id: hal-00534079 \\ https://hal.science/hal-00534079
}

Submitted on 8 Nov 2010

HAL is a multi-disciplinary open access archive for the deposit and dissemination of scientific research documents, whether they are published or not. The documents may come from teaching and research institutions in France or abroad, or from public or private research centers.
L'archive ouverte pluridisciplinaire HAL, est destinée au dépôt et à la diffusion de documents scientifiques de niveau recherche, publiés ou non, émanant des établissements d'enseignement et de recherche français ou étrangers, des laboratoires publics ou privés. 
Geological and thermal conditions before the major Palaeoproterozoic goldmineralization event at Ashanti, Ghana, as inferred from improved thermal modelling.

\author{
Virginie HARCOUËT ${ }^{1-2,(3)}$, Laurent GUILLOU-FROTTIER ${ }^{1,\left(^{*}\right)}$, Alain BONNEVILLE ${ }^{2}$, \\ Vincent BOUCHOT ${ }^{1}$ and Jean-Pierre MILESI ${ }^{1}$
}

1:BRGM, Orléans, France

2: Institut de Physique du Globe, Paris, France

Revised manuscript submitted to Precambrian Research, July $12^{\text {th }}, 2006$

(*) : Corresponding author: L. Guillou-Frottier, BRGM, Mineral Resources Division, 3 av. C. Guillemin, BP 6009, 45060 Orléans Cedex 2, France; tel : +3323864 47 91; fax : +3323864 36 52; e-mail address : 1.guillou-frottier@brgm.fr

(3) : Present address : V. Harcouët, Ocean Hemisphere Research Center, Earthquake Research Institute, University of Tokyo, 1-1-1, Yayoi, Bunkyo-ku, 113-0032 Tokyo, Japan; 


\section{Abstract}

Heat transfer processes before a major mineralizing event in the Paleoproterozoic continental crust of southern Ghana are the subject of a detailed regional thermal modelling study. The area of the Ashanti belt is the most mineralized for gold in West Africa, and it is believed that prior to the main gold mineralization event, crustal-scale thermal processes may have played a critical role in ore deposit formation. The thermal regime before and after the crustal shortening events that affected the region during the Eburnean orogeny (2130 to $1980 \mathrm{Ma}$ ) is calculated just before the main mineralization event which corresponds to late orogenic hydrothermal gold deposit formation. Measured thermal properties of lithological units are incorporated into the model, which is geometrically constrained by field studies. Computed pressure-temperature paths, compared to thermobarometric data, allow calibration of the model parameters. The temperaturedependence of thermal properties and the influence of compaction on vertically-varying conductivities have been considered in the crustal-scale thermal modelling. The predictions from this model indicate that the most probable mantle heat flow value at this time in the region of the Ashanti belt is $\sim 30 \mathrm{~mW} . \mathrm{m}^{-2}$. Such a value is two to three times higher than present-day values below stable cratonic areas and could be considered as an upper limit in geodynamic models of the Paleoproterozoic mantle. This relatively high value might be related to the thermal input from a Paleoproterozoic mantle event such as a mantle plume, as previously suggested by several authors to explain metallogenic crises in West Africa. The P-T paths inferred from numerical modelling also allow discrimination between extreme geological scenarios. Indeed, the results of the modelling suggest that the basement is likely to be of continental rather than of oceanic type in the Ashanti area.

Keywords : Palaeoproterozoic, Ashanti, thermal modelling, mantle heat flow 


\section{Introduction}

The thermal state of the crust and of the lithospheric mantle greatly influences global geodynamics and plate tectonics and is thought to have played a major role in the formation of several classes of ore deposits (e.g. Sillitoe, 1972; Barley et al. 1998; De Boorder et al. 1998; Isley and Abbott 1999; Pirajno 2001; Goldfarb et al., 2001). Thermal models of mineralized areas, constrained by pressure-temperature data may thus give an insight into the particular thermal processes related to formation of giant ore deposits. The Ashanti belt in Ghana (Figure 1) is particularly well-suited to this kind of study as it hosts the largest known gold deposits in West Africa, and contains potential resources of more than 1500 tons of gold (Milesi et al. 1991; Pigois et al. 2003). At this location, mineralization is temporally related to the late stage of the Eburnean orogeny, which took place between 2130 and $1980 \mathrm{Ma}$, and affected the supracrustal rocks of the region (Blenkinsop et al., 1994).

The large-scale thermal regime of the crust is controlled by transient heat transfer processes caused by tectonics, by spatial distribution of heat production, and by the amount of heat originating from the mantle, i.e. the mantle heat flow. As they could not be constrained by literature, small-scale or local phenomena, such as partial melting or hydrothermal convection, are not considered in this study. Tectonic processes, crustal composition and geological data alone, inferred from previous studies, were introduced into the thermal modelling, which aimed to enable the estimation of the most probable mantle heat flow values. A first thermal numerical modelling approach using a simple geological scenario and mean thermal properties allowed characterization of the thermal regime of the Ashanti and surrounding belts, prior to and throughout the collisional tectonics that preceeded gold mineralization (Harcouët et al., 2005). This first study concluded that the value of the mantle heat flow in the Ashanti belt prevailing just before the main auriferous 
mineralizing event, approaches 55-60 $\mathrm{mW} \cdot \mathrm{m}^{-2}$, which seems high compared to the present day value of 10-16 mW.m $\mathrm{m}^{-2}$ below stable Archean or Proterozoic cratonic areas (Guillou et al., 1994; Jaupart and Mareschal, 1999; Kukkonen and Peltonen, 1999; Rolandone et al., 2002). In fact, the determination of possible mantle heat flow values during Archean and Proterozoic times should allow constraining of geodynamic models on mantle flow beneath primary continents, and thus on past mantle dynamics. For example, numerous studies have already reproduced the continent-induced thermal blanketing effect (e.g. Guillou and Jaupart, 1995; Lenardic and Kaula, 1995; Trubitsyn et al., 2003). In addition, the consequences on lithospheric thickness have been reviewed by Jaupart et al. (1998) and Jaupart and Mareschal (1999), who emphasized the need to determine thermal conductivity in the cratonic mantle. Several other studies have related surface heat flow to lithospheric thickness (e.g. Artemieva and Mooney, 2001), but the inferred mantle heat flow values do not compare to previously mentioned estimates (e.g. Superior Province, Canada, Kaapval craton, south Africa). Hence, one objective of this study is to improve the previous numerical model in order to obtain the most reliable mantle heat flow value for the period corresponding to two million years ago, while considering a more realistic geological scenario, and accounting for temperature-dependence of thermal properties.

The present work thus complements the first study and consists of a multi-objective approach. Firstly, thermal modelling is used to determine the crustal thermal structure corresponding to the period immediately prior to the gold deposit formation that took place around $2100 \mathrm{Ma}$ in Ghana (Oberthür et al., 1998). Secondly, the role of depth and temperature dependent thermal parameters on the crustal-scale thermal field will be investigated in detail. Finally, the thermal modelling also provides new insight into the crustal structure of the Ashanti region. 
The model prediction is strongly dependent on thermal parameters, such as thermal conductivity values and heat-production rates. Whereas the latter are constant as a function of temperature, this is not the case for thermal conductivity. Indeed, different laws, based on measurements of thermal conductivity $(\lambda)$ as a function of temperature $(T)$, demonstrate a decrease of $\lambda$ with increasing $T$. Such a dependence may be of importance given the direct influence of this parameter on the thermal field; a lower thermal conductivity tending to increase the temperature. Thus if the temperature dependence of the thermal conductivity is taken into account, a decrease of the deduced value of mantle heat flow should be obtained. It is therefore of interest to perform numerical modelling including this temperature dependence in order to obtain more accurate and more reliable estimates of mantle heat flow values.

In addition, the numerical modelling examines various geological scenarios based on available field data. The crustal structure in the Ashanti region is still a controversial subject (see section 3.2.2) and numerical modelling may allow validation of a particular scenario. The lack of geophysical data or deep drilling in this area prevents the structure and nature of the basement from being constrained. Two different scenarios are tested: one with an Archean basement below the whole region and a second one in which the basement is absent below the western units. In all cases, thermobarometric data are the main constraints. As a consequence, our results uncover the nature of the basement in the region, highlight the effects of temperature and depth dependence of thermal conductivity and provide quantitative constraints on the deep thermal processes prevailing immediately prior to the main gold mineralizing event that took place in Ghana at $\sim 2100$ Ma.

\section{Geological setting and tectonic framework for thermal modelling}

In the following, a geological description of the area is presented using generally recognized terminology. However, for the purpose of this study, which is based on thermal 
modelling, some terms are used to describe the chosen geological scenario. To avoid possible confusion between this and the following sections, lithological units are defined as follows:

- Greenstone belt: lithological unit mainly consisting of green mafic volcanic rocks (basalts), some felsic volcanic rocks and increasing amounts of sediment toward the top of the unit

- Basin: lithological unit consisting of detrital (e.g. conglomerates) and / or chemical sedimentary rocks

- Monzogranite complex: lithological unit consisting of anatectic products, derived from previous metasedimentary rocks and orthogneiss.

The geology of Ghana is characterized by Palaeoproterozoic rocks (Figure 1a) which belong to the Birimian Supergroup and the Tarkwaian Group. The Birimian Supergroup includes sedimentary basins (e.g. Afema basin) separated by sub-parallel NE-trending greenstone belts consisting of volcanic rocks (basalts dominant on rhyolites) and some interflow sediments. The Tarkwaian basin (conglomerates and phyllites) overlie and rework the Birimian rocks and are assumed to be derived from the erosion of these rocks.

A multi-stage sequence of events based on chronological and structural analysis has been proposed to define the successive emplacement of the different lithological units, their deformation during the two distinct phases designated by D1 and D2, and their geometric relationships (Figure 1b).

\subsection{Initial accretion and two tectonic phases}

A phase of magmatic accretion has been identified between 2250 and $2170 \mathrm{Ma}$, corresponding to a period of volcano-plutonism, leading to the emplacement of the greenstone belts (Feybesse et al., 2000). These belts were emplaced as subparallel volcanic ridges (Leube and Hirdes, 1986; Leube et al., 1990; Taylor et al., 1992; Oberthür et al., 
1998). Nevertheless there is still no general agreement about the tectonic environment associated with their emplacement and various contexts have been envisaged. Indeed, Leube et al. (1990) postulated that the volcanic belts originated as chains of volcanic islands developed during intracontinental rifting. On the other hand, Sylvester and Attoh (1992) suggested that they probably originated as immature island arcs, built on an oceanic crust while Abouchami et al. (1990) concluded that the volcanic belts closely resemble accreted oceanic plateaus, Davis et al. (1994) favouring an oceanic environment for formation of most of the volcanic belts.

The addition of extensive monzogranitic plutonism occurred between 2160 and 2150 Ma (Opare-Addo et al. 1993b, Feybesse et al. 2000). Based on geochronological and isotopic data, Taylor et al. (1992) assumed that the Birimian of Ghana forms part of a major Proterozoic episode of juvenile crustal accretion which has also been recognized in other surrounding areas in West Africa and dated at 2100-2200 Ma by Abouchami et al. (1990). After this crust-formation stage, basin opening and sedimentation took place within the Birim, Afema and Comoé basins between 2150 and 2100 Ma. Geochronological data imply that the volcanic belts and older granitoids were the source of a significant part of the sediments that formed the Birimian sedimentary basins (Davis et al., 1994; Oberthür et al., 1998). As part of the sedimentation occurred contemporaneously to the onset of the Eburnean orogeny (see following paragraph) these basins were assumed to be foreland basins by Feybesse et al. (2000). Davis et al. (1994) suggested that the formation of these sedimentary basins were probably the result of accretion of arcs and oceanic plateaus as they support the idea of an oceanic environment.

The emplacement of the Birimian rocks was followed by a period of tectonic accretion, the Eburnean orogeny, which is marked by two major syn-metamorphic phases D1 and D2 that are distinguished by chronological criteria. 
The D1 deformation is associated with the initial contractional tectonism that took place between 2130 and 2105 Ma (Boher et al., 1992; Feybesse and Milesi, 1994). This compressive phase along a SE-NW direction with a northwestward vergence results in crustal thickening by stacking of different lithological units (Feybesse et al., 2000). During shortening, the Birimian rocks were deformed, metamorphosed, and subsequently uplifted and eroded.

The resulting Tarkwaian detrital rocks were deposited between $2133 \pm 4$ and $2097 \pm 2$ Ma (Oberthür et al. 1998; Pigois et al. 2003). Based on the presence of foliated clasts of Birimian in Tarkwaian and on the age of the youngest detrital zircons in each formation, these deposits were interpreted as not being affected by D1 deformation but probably deposited either at the end of D1 or during the first stages of the D2 phase (Milesi et al. 1991; Allibone et al., 2002a)

The D2 deformation, affecting both the Tarkwaian and Birimian rocks, began at around 2105-2095 Ma (Feybesse et al., 2000; Pigois et al., 2003). This tectonometamorphic phase is associated with important regional folding structures and major shear zones orientated NE-SW, with a southeast vergence, such as the Ashanti fault acting as a thrust fault. Indeed, Tarkwaian conglomerates present folds and a foliation associated to this D2 phase (Kesse, 1985; Ledru et al., 1994). These rocks have been locally overthrusted by Birimian rocks, notably along the Ashanti fault.

\subsection{Gold mineralisation phase}

Three gold-forming events are recorded in the gold Province: (1) a supposed earlier mineralization reworked in the Tarkwaian conglomerates, (2) a paleoplacer type e.g. (Tarkwa) and (3) a late-orogenic one (e.g.. Ashanti).

These gold-bearing conglomerates of Tarkwaian Banket formation (paleoplacer type) were deposited mainly between $2104 \pm 6 \mathrm{Ma}$ (age of the youngest detrital zircon, Milesi et 
al. 1989) and $2097 \pm 2 \mathrm{Ma}$ (age of the Banso granitoid that is assumed to intrude the Tarkwaian deposits, Oberthür et al. 1998).

The major epigenetic Birimian lode-gold event occurred late in the Eburnean orogeny, after the peak of metamorphism was reached (Oberthür et al., 1998; John et al., 1999; Yao et al., 2001; Pigois et al. 2003). The age of hydrothermal alteration has been determined by Oberthür et al. (1998), who give ages of $2092 \pm 3$ and $2086 \pm 4$ Ma (on hydrothermal rutile). A younger age at $2063 \pm 9 \mathrm{Ma}$ (SHRIMP II U-Pb on hydrothermal xenotime) has also been proposed by Pigois et al. (2003). These age estimations enable constraining of the most likely period of the Ashanti mineralisation to coincide with the late stage of D2 phase. After the thrusting D2 stage (peak of metamorphism), gold mineralization emplacement is controlled by a strike-slip movement of the Ashanti fault (Allibone et al., 2002a,b, and Figure 1b).

Most of the gold deposits are concentrated along the western flank of the Ashanti belt and are interpreted as having been been emplaced at pressures ranging from 1 to $4 \mathrm{kbar}$ and temperatures between 200 and $450^{\circ} \mathrm{C}$ (Oberthür et al., 1997; Schmidt Mumm et al., 1997; John et al., 1999; Yao et al., 2001; Klemd et al., 2002). The main gold deposits (e.g. Obuasi, Bogosu, Konongo) are controlled by the Ashanti fault zone, which is located at the contact between the Birimian sedimentary basins, Tarkwaian conglomerates and Ashanti volcanic belts.

\section{Geological scenario for modelling: syn-Eburnean crustal evolution}

\subsection{Thermobarometric constraints}

Previous field studies have provided several pressure-temperature estimations, which are taken into account in this study. They are presented in Table 1 and detailed below.

\subsubsection{Pre-Eburnean:}


In the monzogranites, the presence of deformed neosomes indicates an anatectic event that began just before D1 stage at a deep crustal level, around 6 kbars (Feybesse, comm. pers., 2004; Harcouët et al., 2005). At this pressure, equivalent to a depth of $22.5 \mathrm{~km}$, the temperature conditions required for partial melting to occur fall between $650{ }^{\circ} \mathrm{C}$ and $800^{\circ} \mathrm{C}$, depending on water content (e.g., Wyllie, 1977).

\subsubsection{D1 deformation:}

To the east of the Ashanti belt, banded orthogneiss (monzogranite unit) were transported under anatectic conditions during D1 (stacking) onto sediments of the Birim Basin (Feybesse and Milesi, 1994). Thermobarometric studies indicate that these sediments were buried to a depth of $\sim 18 \mathrm{~km}(\mathrm{P}=\sim 5-6 \mathrm{~kb})$ (Opare-Addo et al., 1993a,b). Despite there being no general consensus regarding the metamorphic conditions reached by the sediments, in this study, as in our previous work (Harcouët et al 2005), we chose to compare our results with a general greenschist facies. Indeed, according to previous field campaigns (Feybesse et al., 2000), regional metamorphism in the sedimentary basins reached greenschist facies, higher metamorphic facies being reached locally at the contact with some late granitoids.

\subsubsection{D2 deformation:}

Locally the D2 deformation results in thickening and burial of both the Tarkwaian conglomerates and of the Ashanti volcanic belt. The metamorphism related to D2 ranges from upper greenschist facies to mid-amphibolite facies (Kleinschrot et al. 1993; John et al. 1999; Klemd et al. 2002; Pigois et al 2003). The thermobarometric conditions, ranging from $450{ }^{\circ} \mathrm{C}$ at $3.5 \mathrm{kbar}$ to $600{ }^{\circ} \mathrm{C}$ at $5 \mathrm{kbar}$ indicate that some of the Tarkwaian conglomerates were buried to depths of 10 to $15 \mathrm{~km}$ (Milesi et al., 1989; Ledru et al., 1994). The greenstones of the Ashanti volcanic belt were also buried during the D2 phase, with a 
metamorphic peak corresponding to $4-6$ kbar and temperatures of 490 to $650{ }^{\circ} \mathrm{C}$ (John et al., 1999; Klemd et al., 2002; Pigois et al., 2003).

\subsection{Structural constraints}

In addition to thermobarometric constraints that define $T(z)$ points within the crust, vertical and horizontal thermal gradients $(\partial T / \partial z)$ and $(\partial T / \partial x)$, and thus crustal thermal field $T(x, z)$, strongly depend on the geometries of each lithological unit. Particular attention to thicknesses and lateral extents of each unit was thus necessary and is described below.

\subsubsection{Dimensions of the lithological units}

The dimensions of the different rock units are generally the same as the ones presented in Harcouët et al. (2005). Lateral extents are estimated with present-day geological data. A mean lateral extent of $40 \mathrm{~km}$ for all the different rock units is chosen. The thicknesses of lithological units are mainly constrained by thermobarometric data and are as follows: $30 \mathrm{~km}$ for the crust, $23 \mathrm{~km}$ for the monzogranites, $6 \mathrm{~km}$ for the sedimentary Afema and Birim basins and between 3 and $4 \mathrm{~km}$ for the Tarkwaian conglomerates (Figure 2a).

From the estimations of Sylvester and Attoh (1992) and Pigois et al. (2003), the Birimian basic volcanic sequences were characterized by an original thickness of 4 to 12 $\mathrm{km}$, whereas Junner (1940) previously proposed a thickness of 10 to $15 \mathrm{~km}$. Results presented in the following section correspond to models for which a thickness of $12 \mathrm{~km}$ is assumed

\subsubsection{Nature of the basement}

There is still no general agreement concerning the nature (oceanic vs continental) of the basement in Ghana. The absence of Archean rocks and the low level of exposure of basement rocks in this region of Ghana have lead some authors to suggest that basement was absent below some of the Birimian units. Neither direct geochronology nor indirect 
isotopic method used by Taylor et al. (1992) provide evidence for the involvement of an Archean basement in the petrogenesis of the volcanics, the Birimian sediments, or of numerous granitoids that they investigated except those of the Winneba area. However, the basic nature of the magmatism implies a deep (mantle) source and the absence of contamination could be explained by a rapid ascension of this material. Besides, the traces of contamination presented by the Winneba granite in south-east Ghana indicate the presence of Archean basement, at least in this region (Taylor et al., 1992; Opare-Addo et al., 1993b). The presence of an Archean basement is also suggested by the recent discovery of diamantiferous tuffisite clastic dykes in the Birim river basin (Milesi et al., 2004).

In any case, the presence of an Archaean basement has therefore been proposed beneath the Birim basin and southeastern Ghana, but the type of basement underlying the Ashanti belt is still controversial. The Ashanti belt might represent the boundary of a continental domain, with the basement below this belt and the western units possibly being of oceanic type. Both hypotheses have been tested by numerical modelling in this work.

\subsection{Deduced geological scenario}

The simple geological scenario proposed in Harcouët et al. (2005), which focussed on the D1 tectonic phase alone and assumed a continental basement below the whole area, has been improved by introducing (1) the D2 deformation phase and (2) a varying basement composition. Episodes of partial melting were not accounted for in the scenario since they are considered as affecting the crust locally and within short time intervals, contrary to large-scale heat transfer processes induced by tectonics. The granitoids associated with partial melting play a role in contact metamorphic grades that are reached locally, but they should not affect regional metamorphism. As metamorphism is the key process analyzed in this study it is important to consider regional metamorphism rather than local metamorphism. 
The stage just before $2130 \mathrm{Ma}$ represents the initial condition for the numerical modelling. At that time, all the lithological units except the Tarkwaian conglomerates were emplaced. From west to east, the $40 \mathrm{~km}$-wide units are: the Afema basin, the Ashanti volcanic belt, the Birim basin, the Kibi belt and the monzogranites complex (Figure 2).

The initial stage of tectonic accretion, D1, which began at 2130 Ma resulted in unit stacking, whose thickness has been evaluated using thermobarometric data associated with the sediments of the Birim basin that were buried to a depth of $\sim 19-22.5 \mathrm{~km}(\sim 5-6 \mathrm{kbar})$. The tectonic evolution during this stage is represented by several thrusts and the result is illustrated in Figure 2. The Kawere detrital unit was deposited on the Ashanti belt during D1 (Figure 2b). It contains polymictic barren conglomerates deposited after $2132 \pm 2 \mathrm{Ma}$ (age of the youngest detrital zircon from the base of the series; Davis et al., 1994; Oberthür et al., 1998).

The Tarkwaian gold-bearing conglomerates from the Banket series are the products of a stage of uplift and erosion which followed D1 thickening. As a consequence of isostatic response to burial, the unit that is the most overthrusted, the Birim sedimentary basin, is the most affected by erosion and uplift. Indeed, Allibone et al. (2002b) note that the Birimian sediments at Obuasi are downward facing, indicating a large-scale overturning and refolding of stratigraphy and therefore significant deformation on this structure. The erosion rate between the regional D2 peak metamorphism (2100-2105 Ma) and the end of deposition of the Tarkwaian Banket series (2097 Ma) is constrained by the presence of foliated mineralized pebbles of quartz in the Banket conglomerate (Milesi et al., 1989). Moreover, it has been reported that pebbles of quartz show the same textures and fluid inclusion compositions as those of post-Banket Ashanti veins, suggesting that they formed under similar conditions (Klemd et al. 1993), at a depth of $\sim 4-15 \mathrm{~km}(\sim 1-4 \mathrm{kbars})$ (Oberthür et al. 1997; Schmidt Mumm et al. 1997; John et al. 1999; Yao et al. 2001). This 
implies erosion of 4 to $15 \mathrm{~km}$ of strata within the $10 \mathrm{Ma}$, separating the end of D1 stacking from the beginning of D2 deformation. Therefore, based on these geological constraints an erosion rate of $1 \mathrm{~km} / \mathrm{Ma}$ is assumed.

Numerical calculations are greatly simplified by keeping the Earth surface flat during thrusting events, which - at the time scale of the model - can be considered as 'instantaneous' (see Harcouët et al., 2005, for the physical justification of the hypothesis of instantaneity).

\section{Thermal parameters}

In order to introduce petrophysical constraints into the model, measurements of thermal conductivity and heat-production rates were performed on representative rock samples collected in Ghana (greenstones, monzogranites, sediments and Tarkwaian conglomerates) and Guinea (basement and sediments).

\subsection{Mean Thermal properties}

Measurements of thermal conductivity were performed by using a QTM (Quick Thermal conductivity Meter) and heat-production rates at $2100 \mathrm{Ma}$ were inferred from measurements of present-day concentrations of radiogenic elements $U, K$, and Th. The methods used to measure these thermal properties and to calculate heat-production at 2100 Ma are detailed in Harcouët et al. (2005). Table 2 summarises mean thermal properties used in this study.

\subsection{Depth-dependent thermal conductivity}

The averaged value of thermal conductivity of sediments is around $2.0 \mathrm{~W} / \mathrm{m} / \mathrm{K}$ but it varies significantly with the origin of sediment and porosity (see details in Clauser and Huenges, 1995). The fact that the thermal conductivity of Birimian sediments and conglomerates approaches $3 \mathrm{~W} \cdot \mathrm{m}^{-1} \cdot \mathrm{K}^{-1}$ is likely to be the result of high compaction and 
metamorphism. Because the porosity of sedimentary and conglomeratic rocks decreases exponentially in response to compaction (Serban et al., 2001), compaction plays a major role in the variation of thermal conductivity within uppermost kilometres of the crust for these types of rocks. For this reason, the variation of thermal conductivity with depth has been investigated in detail.

In this work, thermal conductivity, thermal capacity and specific heat depend on temperature for all types of rock and also on compaction for sedimentary rocks. The influence of variation of these thermal parameters on the mantle heat flow has been investigated.

Measurements of thermal conductivity $(\lambda)$ as a function of temperature have demonstrated a strong temperature dependence of $\lambda$ (Zoth and Hänel, 1988; Seipold, 1998; Vosteen and Schellschmidt, 2003). These experiments enabled prediction of the variation of thermal conductivity with temperature. In this study, the relationship proposed by Vosteen and Schellschmidt (2003) to describe the variation of thermal conductivity for magmatic and metamorphic rocks as well as for sedimentary rocks (for the rock matrix) is used. It describes the decreasing trend of thermal conductivity when temperature increases and is given by the following formulas:

$$
\lambda(T)=\frac{\lambda(0)}{0.99+T\left(a-\frac{b}{\lambda(0)}\right)}
$$

with, $\mathrm{a}=0.0030 \pm 0.0015$ and $\mathrm{b}=0.0042 \pm 0.0006$ for "crystalline" (including metamorphic and volcanic) rocks at $0<\mathrm{T}<500^{\circ} \mathrm{C}$ and $\mathrm{a}=0.0034 \pm 0.0015$ and $\mathrm{b}=0.0039 \pm 0.0014$ for sedimentary rocks at $0<\mathrm{T}<300{ }^{\circ} \mathrm{C}$, and with $\lambda(0)$ being calculated for these rocks, respectively as:

$$
\lambda_{c r y}(0)=\lambda(25) \times 0.53+\frac{1}{2} \sqrt{1.13 \lambda(25)^{2}-0.42 \lambda(25)}
$$




$$
\lambda_{\text {sed }}(0)=\lambda(25) \times 0.54+\frac{1}{2} \sqrt{1.16 \lambda(25)^{2}-0.39 \lambda(25)}
$$

This temperature-dependence is comparable to those observed previously (e.g. compilation of Clauser and Huenges, 1995). Furthermore, the formula of Vosteen and Schellschmidt (2003) correlates with previous trends, and in particular the one from Zoth and Hänel (1988) which is quoted for temperatures as high as $1200^{\circ} \mathrm{C}$. According to Clauser and Huenges (1995), radiation affects the trend of decreasing $\lambda$ with increasing $T$ observed for most rocks (volcanic, plutonic and metamorphic) only around temperatures exceeding 850$900^{\circ} \mathrm{C}$; a temperature range not applicable to this study. Therefore, the formula of Vosteen and Schellschmidt (2003) has been interpolated to temperatures reaching $850-900{ }^{\circ} \mathrm{C}$ for crystalline rocks and $400{ }^{\circ} \mathrm{C}$ for sedimentary rocks.

In order to take into account the effect of porosity in the case of sedimentary and conglomeratic rocks, the following geometric formula has been used (Demongodin et al., 1991):

$$
\lambda(T)=\lambda_{m}(T)^{1-\phi} \lambda_{f}(T)^{\phi}
$$

This relationship enables calculation of the total rock thermal conductivity introducing $\lambda_{m}$, the rock matrix thermal conductivity, $\lambda_{f}$ the one from the intersticial fluid and $\Phi$ is the porosity of the sediments.

The intersticial fluid is assumed to be equivalent to pure water, for which thermal conductivity can be calculated as a function of temperature as follows (Kappelmayer and Haenel, 1974):

$$
\begin{array}{lr}
\lambda_{\text {water }}(T)=0.56+0.003 T^{0.827} & 0 \leq T \leq 50^{\circ} \mathrm{C} \\
\lambda_{\text {water }}(T)=0.442+0.0519 \log T & T>50^{\circ} \mathrm{C}
\end{array}
$$

In addition, the effect of compaction on porosity is directly related to the depth of burial. Serban et al. (2001) proposed an exponential decrease of porosity with depth: 


$$
\phi=\phi_{0} \times e^{(-z / l)}
$$

where $\mathrm{z}$ is the depth of burial, $\phi_{0}$ the surface porosity and $l$ the characteristic length for the decrease of porosity (typically on the order of 1-2 km).

Combining all these laws, the thermal conductivity of sedimentary rocks $\left(\lambda_{\text {sed }}\right)$ can be obtained as a function of depth and temperature, it can be calculated as follows:

$$
\lambda_{\text {sed }}(T, z)=\lambda_{m}(T)^{\left(1-\phi_{0} e^{(-z / l)}\right)} \times \lambda_{f}(T)^{\phi_{0} e^{(-z / l)}}
$$

In this study, the thermal conductivity measured by the QTM technique is assimilated to the thermal conductivity at $25^{\circ} \mathrm{C}$. We also assumed a surface porosity of $50 \%$ and a characteristic length $l$ identical to the one taken by Serban et al. (2001), $1400 \mathrm{~m}$.

Figure 3 illustrates the thermal conductivity of sedimentary rocks as a function of depth. It dissociates the effects of compaction and temperature. For a fixed geothermal gradient of $30^{\circ} \mathrm{C} / \mathrm{km}$, which corresponds to the temperature gradient in the Ashanti belt at 2 Ga necessary to reach $\sim 700{ }^{\circ} \mathrm{C}$ at $23 \mathrm{~km}$ depth, the decrease in thermal conductivity with increasing temperature and, inversely, the increase in thermal conductivity with increasing depth (related to compaction) are visible. When the effects are coupled, the effect of compaction is most important until a depth of about $1 \mathrm{~km}$ and the thermal conductivity increases, then the tendency is reversed and temperature plays the major role, thermal conductivity decreases.

In the case of crystalline rocks, the effect of temperature alone has been taken into account and the variation of thermal conductivity with temperature is close to the one shown on the figure $(\lambda=f(T))$.

\section{$5 \quad$ Thermal modelling}

The source code THERMIC, used to solve the heat equation corresponding to conductive and advective transfers in two dimensions, was developed by Bonneville and 
Capolsini (1999). It is based on a finite-element method and is detailed in Harcouët et al. (2005).

The original code has been modified in order to take erosion and deposition processes into account as well as instantaneous thrusting. Technically an Eulerian approach is used to reproduce the erosion phenomenon so that, for an erosion rate of $1 \mathrm{~km} / \mathrm{Ma}$, at each time step (1 Ma), in the eroded area, elements and their thermal properties are brought up by a vertical distance equivalent to $1 \mathrm{~km}$. Tests were performed to validate the modifications, and results were checked with previously published models, such as those of Nisbet and Fowler (1982a,b) .

The model consists of a rectangular grid $200 \mathrm{~km}$ long (5 units of $40 \mathrm{~km}$ ) and $150 \mathrm{~km}$ thick representing the crust and the lithospheric mantle. The grid is divided into 112004 node isoparametric elements of 1 by $1 \mathrm{~km}$, down to $55 \mathrm{~km}$ depth.

The chosen boundary conditions involve a constant deep heat flow $q_{m}$ imposed at the base of the grid, a fixed surface temperature $\left(T=0{ }^{\circ} \mathrm{C}\right)$, and zero lateral heat flow on the sides. Various values of mantle heat flow $\left(q_{m}\right)$ are used in order to adjust thermobarometric data from the pre-Eburnean stage to the different stages of Eburnean tectonism. Additional details on the numerical procedure and boundary conditions can be found in Bonneville and Capolsini (1999) and Harcouët et al. (2005).

\section{Results}

\subsection{Palaeoproterozoic mantle heat flow}

Presently, in Ghana, the estimated value of surface heat flow ranges between 37 and $42 \mathrm{~mW} \cdot \mathrm{m}^{-2}$ (Beck and Mustonen, 1972; Lucazeau et al., 1991). It is likely that the surface heat flow was higher at $2100 \mathrm{Ma}$, notably because of a radiogenic heat-production rate about 1.7 times higher than present day. Tests performed in this study allow a range of 
possible mantle heat flow at that time, that would be consistent with the interpreted thermobarometric conditions just before and during the Eburnean tectonism (Table 1).

In this section the results for the continental basement alone are shown, the ones for the oceanic case are the subject of a further discussion (see section 6.2).

\subsubsection{Initial stage:}

First, to constrain the pre-thrusting stage, the results of the model have to fit the thermobarometric conditions related to the partial melting reported in the monzogranites, say $650-800{ }^{\circ} \mathrm{C}$ at $\sim 6$ kbar. Different values of mantle heat flow have been tested and it appears that such conditions are reached only if the amount of heat is sufficient at the base of this unit. In addition, models where the temperature at the base of the crust exceeds 850$900{ }^{\circ} \mathrm{C}$ were rejected, these values being already considered as "intermediate to high" by Ranalli (2000). It is clear that the presence of a temperature close to $\sim 850-900{ }^{\circ} \mathrm{C}$ at a 30 $\mathrm{km}$ depth, regionally $(\sim 200 \mathrm{~km})$, would be the result of particular thermal processes that the present modelling should enable to provide evidence for. It is also of note that a high temperature at the base of the crust would be consistent with the presence of large amount of magmatic rocks found in the field.

Using heat production rates listed in Table 2 and accounting for depth-dependent thermal conductivity (equation 6), mantle heat flow values are varied to recover thermobarometric constraints. This results in a minimum mantle heat flow leading to $\sim 650{ }^{\circ} \mathrm{C}$ at $23 \mathrm{~km}$ is $26 \mathrm{~mW} \cdot \mathrm{m}^{-2}$ (Figure $4 \mathrm{a}$ ). For mantle heat flow values lower than 29 $\mathrm{mW} \cdot \mathrm{m}^{-2}$, the $700^{\circ} \mathrm{C}$ isotherm is located beneath the base of the monzogranitic unit, and for values higher than $31 \mathrm{~mW} \cdot \mathrm{m}^{-2}$, temperatures at the base of the crust unit exceed $900{ }^{\circ} \mathrm{C}$. In other words, a very narrow range of mantle heat flow values fit both the chosen geological model and petrophysical constraints. The values of mantle heat flow have to range between 26 and $31 \mathrm{~mW} \cdot \mathrm{m}^{-2}$ to fit initial thermobarometric constraints (Figure 4a,b). For example, 
the mean value of $29 \mathrm{~mW} \cdot \mathrm{m}^{-2}$ leads to $700{ }^{\circ} \mathrm{C}$ at $23 \mathrm{~km}$ depth and a maximum temperature of $865^{\circ} \mathrm{C}$ at the base of the crust (Figure $4 \mathrm{c}$ ).

In order to validate the modelling during the different stages of Eburnean tectonism, syn-D1 P-T paths from Birim basin sediments and syn-D2 P-T paths from Tarkwaian conglomerates and greenstones within the Ashanti belt were investigated. They were computed by recording pressure-temperature values for specific rocks at each time step of the calculation. These paths are illustrated in Figure 5.

\subsubsection{P-T path during D1}

For the sediments originally located at the base of the Birim basin (18 km depth after thrusting), the calculations leads to a retrograde P-T path as the rock travels towards the surface until it reaches its final location at $8 \mathrm{~km}$ depth (Figure 5a). The computed peak P-T conditions, where the maximum temperature is reached, $\left(360{ }^{\circ} \mathrm{C}\right.$ at $\left.3,6 \mathrm{kbar}\right)$ agree with thermobarometric data corresponding to mid-greenschist facies conditions. Field observations suggest that higher metamorphic facies are sometimes associated with lateintrusions within the sedimentary basins, however these facies are not reached in this model since partial melting is not considered in this modelling approach. It can be noted that the retrograde P-T path is representative of the response to rapid burial followed by ehumation, with an increase in pressure during the first million years and then a clockwise P-T path corresponding to thermal rebound during the erosion phase.

\subsubsection{P-T path during D2}

The P-T paths of the greenstones (e.g. Ashanti belt) and Tarkwaian conglomerates, resulting from the burial of the Ashanti belt by $15 \mathrm{~km}$ of rocks are presented in Figure $5 \mathrm{~b}$. The calculated P-T peak conditions are close to the thermobarometric estimations. Indeed, within the greenstones the epidote-amphibolite facies is reached with temperatures of $500{ }^{\circ} \mathrm{C}$ at $\sim 6 \mathrm{kbar}$ and the mid-greenschist facies is reached within the Tarkwaian 
conglomerates $\left(350^{\circ} \mathrm{C}\right.$ at $\left.4 \mathrm{kbar}\right)$. These conditions are still somewhat low compared to thermobarometric estimations (Figure 5b) and it is likely that an additional source of heat, such as late to syn-D2 magmatism (Hirdes et al., 1992; Davis et al., 1994; Oberthür et al., 1998) has to be invoked.

From the results of the continental case presented above, the computed P-T paths, during D1 as well as during $\mathrm{D} 2$, are close to the ones given by thermobarometric estimations. The somewhat low temperatures could result from the absence of a magmatic contribution suggested by several previous field studies (Ledru et al., 1994; John et al., 1999; Pigois et al., 2003). Furthermore, some authors (Allibone et al., 2002a,b) add other thrusting events at the beginning of the D2 phase, on the eastern boundary of the Ashanti belt. In the present study, these assumed syn-D2 thrusting events have not been taken into account because of the lack of associated thermobarometric estimations. They could also have contributed to the higher temperatures reached in this region and notably within the greenstones which are located in the SE of the Ashanti belt.

The sensitivity of the modelling results to thermal parameters is evaluated using the same principle as the one described in Harcouët et al. (2005). This evaluation consists of calculating the effect of the different parameter uncertainties (thermal conductivity, heatproduction rate, type of basement) on the deduced mantle heat flow. These calculations lead to the estimations of extreme values of mantle heat flow that can reproduce the thermobarometric data, which for the present case range between 12 and $45 \mathrm{~mW} \cdot \mathrm{m}^{-2}$. For example, when uncertainties in heat production rates for all types of rock are considered, the mantle heat flow values then range from 12 to $45 \mathrm{~mW} \cdot \mathrm{m}^{-2}$ whereas they fall within the range of 20 to $40 \mathrm{~mW} \cdot \mathrm{m}^{-2}$ when the uncertainties in thermal conductivity are taken into account. 


\subsection{Oceanic or continental basement?}

In the case of an oceanic basement, thermal modelling has also been performed in order to investigate the likeliest crustal structure. Indeed, the study of initial P-T conditions and of syn-deformation P-T paths could help determine if the hypothesis of a continental basement is the only valid geological scenario or if an oceanic basement is also possible. As in the continental case the partial melting condition relative to the monzogranites has been taken into account to constrain the thermal regime pre-D1 tectonism. In Figure 6, it appears that in such a case, a mantle heat flow of $37 \mathrm{~mW} \cdot \mathrm{m}^{-2}$ produces results that fit the thermobarometric data at this initial stage $\left(\sim 700^{\circ} \mathrm{C}\right.$ at $\left.23 \mathrm{~km}\right)$. Compared to the continental case, despite a $10 \mathrm{~mW} \cdot \mathrm{m}^{-2}$ higher mantle heat flow value, the temperature is globally lower, because of the reduced amount of heat-production elements caused by the absence of crust below the Western units.

In the case of the oceanic basement model, the trend of the P-T path followed by sediments at the base of the Birim basin is similar to the one from the continental basement case but the peak conditions are slightly lower, $335^{\circ} \mathrm{C}$ at $3.6 \mathrm{kbar}$ (Figure 6b). This similarity is due to the fact that, within the Birim basin region, the overall compositional structure of the crust is not modified. Nevertheless, this result highlights lateral heat transfers within the 2D model section, which act to decrease deep crustal temperatures in western units. The peak temperature is slightly lower in the oceanic case because of the replacement of heat-producing basement by mantle material.

However, when studying syn-D2 P-T paths of rocks from Tarkwaian conglomerates and greenstones from the Ashanti belt (Figure 6c), it is clear that a mantle heat flow of 37 $\mathrm{mW} . \mathrm{m}^{-2}$ does not reproduce the thermobarometric data at these locations. The temperatures are too low in both cases and the P-T field estimates cannot be reached for either rocks. 
Indeed, in the conglomerates the highest temperature reached is $210^{\circ} \mathrm{C}$ and $330{ }^{\circ} \mathrm{C}$ in the greenstones which is far too low compared to the thermobarometric calculated conditions.

As a consequence, the results relative to the oceanic basement do not fit field data and are rejected. The modelling thus pleads in favour of a continental basement in the whole area below southern Ghana, Therefore, this result supports the assumption of a rapid ascension of magma that would explain the absence of traces of contamination within numerous granitoid suites in Ghana demonstrated by Taylor et al. (1992) rather than the absence of continental basement. Nevertheless, radiogenic isotopes data on additional granitoids would be useful to discuss this hypothesis.

\subsection{Effect of the temperature-dependence of thermal parameters}

Most thermal studies in mineralized areas are based on numerical modelling for which thermal properties are assumed to be constant. A few studies introduce temperaturedependent thermal properties, but they generally focus on thermal regimes in sedimentary basins (e.g. Gallagher et al., 1997; Starin et al., 2000). In this work, a variation of thermal parameters as a function of temperature and depth has been introduced. The different consequences of such a dependence are described here.

\subsubsection{Effect on transient temperature field}

The effect of the temperature dependence can be demonstrated first on the thermal parameters. The thermal conductivity decreases when temperature increases (see section 4.1.2). In contrast, the thermal capacity $\left(\rho C_{p}\right.$, where $\rho$ is the density and $C_{p}$ is the specific heat) increases as a response of temperature increase (Vosteen and Schellschmidt, 2003) . The thermal diffusivity being defined as $\lambda / \rho \mathrm{C}_{\mathrm{p}}$, is also temperature dependent and decreases when $\mathrm{T}$ increases, even more rapidly than the thermal conductivity. The lower the value of thermal diffusivity the longer it takes for thermal anomalies to dissipate. Therefore, when the depth/temperature-dependence is taken into account, thermal perturbations related to 
thrusting and erosion need more time to dissipate. As a consequence, temperatures at the time of the thermal peak are delayed. This phenomenon is visible when observing the time lag between thermal peaks for a model where $\lambda=f(z, T)$ compared to a case where $\lambda$ is constant (Figure 7). The thermal peak is delayed in the case where thermal parameters are temperature dependent.

\subsubsection{Effect on mantle heat flow values}

Due to the induced insulating effect, for the same value of mantle heat flow, temperatures are generally higher when thermal conductivity is depth and temperature dependent. Indeed, to fit the initial P-T conditions within the monzogranite complex, a mantle heat flow of only $29 \mathrm{~mW} \cdot \mathrm{m}^{-2}$ is necessary when $\lambda=\mathrm{f}(\mathrm{z}, \mathrm{T})$, whereas it has to reach 55 $\mathrm{mW} . \mathrm{m}^{-2}$ when $\lambda$ is constant. From this observation it is clear that exclusion of the depthdependence leads to an overestimation of mantle heat flow.

Nevertheless, both approaches give deduced mantle heat flow values two to three times greater than the present-day estimated values of 10 to $16 \mathrm{~mW} \cdot \mathrm{m}^{-2}$ below thermally stable areas (Kukkonen and Peltonen, 1999; Rolandone et al., 2002). It must be emphasized that present-day mantle heat flow values beneath Archean and Proterozoic stable areas are not significantly different (e.g. Jaupart and Mareschal, 1999). Such a difference illustrates that the thermal regime in the past was either higher than the present-day one or that mineralizing regions were characterized by the presence of deep thermal perturbations.

\section{Discussion}

The predictions from this study constrain the thermal regime prevailing in the region of the Ashanti belt and surrounding belts during the first stages of the Eburnean orogeny.

When the presence of a continental basement is assumed in the whole region, the results of the thermal numerical modelling correlate with the thermobarometric conditions 
reported in the literature for this region. For instance, mid-greenschist facies conditions are reached by rocks situated in the Birim basin and by the Tarkwaian conglomerates, and upper-greenschist to amphibolite facies conditions are encountered by rocks of the volcanic belts. Therefore, these results are consistent with the regional metamorphism conditions indicated in previous studies (Milesi et al. 1989; Kleinschrot et al. 1993; Ledru et al., 1994; Hirdes et al. 1996; Oberthür et al. 1998; John et al. 1999; Klemd et al. 2002). However, calculated temperatures are somewhat low (by $50-100{ }^{\circ} \mathrm{C}$ ) compared to those estimated thermobarometrically. As imposed in the model at $1 \mathrm{~km} / \mathrm{Ma}$ (see section 3.3), an overestimation of the mean erosion rate can be invoked. In the case of a lower erosion rate of $0.5 \mathrm{~km} / \mathrm{Ma}$, temperatures of the middle crust are enhanced by $50{ }^{\circ} \mathrm{C}$. A likely explanation for this temperature difference is the amount of partial melting, that was not taken into account in this study. Indeed, it is likely that higher temperatures are associated with an additional amount of heat related to late-orogenic magmatism (around 2100-2090 Ma) which has not been modelled.

This work includes examination of the effect of varying thermal conductivity with temperature for all types of rocks and with depth for sedimentary rocks. The results demonstrate that, compared to a previous modelling approach (Harcouët et al., 2005), lower values of mantle heat flow are necessary to fit thermobarometric data $\left(55 \mathrm{~mW} \cdot \mathrm{m}^{-2}\right.$ and 29 $\mathrm{mW} \cdot \mathrm{m}^{-2}$ respectively). To this end, combination of depth and temperature dependence leads to a reduction in the deduced mantle heat flow value. In addition, when depth and temperature dependence is introduced, the thermal diffusivity also decreases when the temperature increases leading to longer dissipation times of thermal anomalies related to thrusting and erosion. This effect is also associated with the attainment of peak metamorphic conditions after a longer period of erosion. The insulation effect resulting from a decrease in thermal conductivity should also result in and/or enhance local partial 
melting at depth. Nevertheless this phenomenon was not reproduced in this study as no constraint on the volume of granitoids could be found in the literature. In addition, it has to be noted that granitoids are observed as discrete patches on the field so that they did not affect regional metamorphism when compared with large-scale lateral heat transfer due to tectonics.

Deep thermal processes beneath continents are well constrained below thermally stable areas for present times (Jaupart and Mareschal 1999; Lenardic et al. 2000) and different studies have shown that mantle heat flow values at the base of the Precambrian crust range from $10 \mathrm{~mW} \cdot \mathrm{m}^{-2}$ to $16 \mathrm{~mW} \cdot \mathrm{m}^{-2}$ (Kukkonen 1998; Russell and Kopylova 1999; Kukkonen and Peltonen 1999; Rolandone et al. 2002). Several authors have suggested that thermal gradients in the Archean may not have differed significantly from the range of modern continental thermal geotherms (Watson, 1978; England and Bickle, 1984; Richter, 1985; Bickle 1986). If this were the case, one would expect similar, low mantle heat flow values at the base of continents in Palaeoproterozoic times, unless some large-scale thermal perturbation affected the base of the crust. Nevertheless, the predictions from our study suggest that mantle heat flow values in the Palaeoproterozoic in Ghana approached 30 $\mathrm{mW} \cdot \mathrm{m}^{-2}$. Such a value is at least two times greater than the proposed present value below Archean and Proterozoic cratons (Guillou et al., 1994; Rolandone et al., 2002). Therefore, this difference could either suggest that the region of the Ashanti belt was thermally unstable or that a higher mantle heat flow existed in the Palaeoproterozoic. If one assumes that the thermal regime in Palaeoproterzoic was similar to the present-day one then this high value could be related to deep thermal perturbations. The presence of a mantle plume below this part of West Africa during the period of gold mineralisation has already been proposed (e.g. Boher et al., 1992). Such an event would corroborate a more important heat supply at the base of the crust, even if a number of other large-scale geodynamic events may also be 
proposed. For example, Groves et al. (2005) suggest changes from Archean to modern-style plate tectonics, as well as catastrophic mantle overturn. The anomalous heat input can also be triggered by dynamic instabilities at the base of the lithosphere, leading to delamination of the mantle lithosphere (e.g. Smithies et al., 2003). Recent models of plume-lithosphere interactions effectively demonstrate the possibility for Rayleigh-Taylor type instabilities at the base of the lithosphere, resulting in lithosphere delamination followed by an increase of the subcontinental heat flow (Burov and Guillou-Frottier, 2005). Whatever the geodynamic explanation could be, the heat input may explain the presence of the early anatexis within the monzogranites and justifies the tectonic evolution of the region which presents alternative compressive and extensive stages, as recently obtained in the previously referenced study. It must be noted that if superevents in the mantle are related to anomalous deep processes, the associated thermal signatures would not necessarily imply strong modifications in mantle heat flow values. In other words, our results show that the thermal equilibrium of the crust can be easily disturbed as soon as mantle heat flow increases by only a few tens of $\mathrm{mW} \cdot \mathrm{m}^{-2}$.

Any further inference from the deduced mantle heat flow value, like the probable mantle temperatures, would be somehow dangerous. Indeed, relationships between mantle heat flow, lithospheric thickness and mantle temperatures are not straightforward since it depends on the assumed crustal composition, on the chosen law for thermal conductivity at high temperatures, and, if the convective boundary layer model is assumed, on the chosen mantle rheology (Jaupart et al., 1998). For present-day values of subcontinental mantle heat flow (10-15 mW.m $\left.\mathrm{m}^{-2}\right)$ lithospheric thicknesses are estimated to range between 200 and 330 km (see details in Jaupart and Mareschal, 1999).

The oceanic case, for which to the west of the Birim basin, the basement is replaced by mantle material, does not produce results consistent with thermobarometric field data. 
Temperatures related to the thermal peak within the greenstones and the conglomerates of the Ashanti belt are far below ones estimated in previous studies. Therefore, models which include a continental basement everywhere are most appropriate for representing the geology of this region. Nevertheless, the geometry of the oceanic model might be too simple. At the transition between the continental and the oceanic domains, the values of mantle heat flow might not be constant, as is the case presently below the Congo basin (Lucazeau et al., 2004). In this case, one should impose a laterally variable value of mantle heat flow, but the data available in the area are too poor to give a precise estimation of such a variation.

\section{Conclusion}

Our numerical model solves for the thermal evolution of southern Ghana during the first stages of the Eburnean orogeny and provides new insights into the regional thermal state of the crust immediately prior to the main Palaeoproterozoic gold mineralizing event. The results of the modelling suggest that a mantle heat flow of about $30 \mathrm{~mW} \cdot \mathrm{m}^{-2}$ prevailed in the Ashanti area 2100 Ma. If the Archean continental thermal regimes were similar to present-day ones then such a value is representative of an anomalously high mantle heat flow, which could be explained by a certain degree of anomalous thermal input below the region before the mineralizing events. This study also emphasizes that the depth and temperature dependence has to be taken into account in order not to overestimate the deduced value of mantle heat flow. Finally, the predictions of the numerical modelling validate a specific crustal structure. Indeed, the results of the modelling suggest the presence of a continental basement below the whole Ashanti region and reject the hypothesis of an oceanic basement. Our study does not take into account fluid circulation nor partial melting, two important processes in the understanding of the small-scale and short-time mineralizing processes. Rather it focuses on estimating the regional thermal 
evolution of the area during tens of Myrs, which in turn is mainly controlled by mantle heat flow and large-scale horizontal tectonics.

Acknowledgements : This study was supported by a BRGM grant and represents the first part of V.H. PhD thesis. The authors would like to thank J. Braun, J-L. Feybesse, J-L. Lescuyer, F. Lucazeau, and A.B. Thompson for fruitful discussions. The authors also wish to thank Dallas Abbott for her valuable comments and suggestions, as well as the other anonymous reviewer for his careful and helpful review. We thank Patrick Romano for proofreading the final manuscript and English editing. This is BRGM contribution BRGMCORP-04020. 


\section{References}

Abouchami, W., Boher, M., Michard, A., Albarede, F. 1990. A major 2.1 Ga event of mafic magmatism in West-Africa: an early stage of crustal accretion. J. Geophys. Res., 95, 17605-17629.

Allibone, A., Teasdale, J., Cameron, G., Etheridge, M., Uttley, P., Soboh, A., Appiah-Kubi, J., Adanu, A., Arthur, R., Mamphey, J., Odoom, B., Zuta, J., Tsikata, A., Pataye, F., Famiyeh, S., Lamb, E. 2002a. Timing and structural controls on gold mineralization at the Bogoso gold mine, Ghana, West Africa. Econ. Geol., 97, 949-969.

Allibone, A., McCuaig, T.C., Harris, D., Etheridge, M., Munroe, S., Byrne, D., Amanor, A., Gyapong, W. 2002b. Structural controls on gold mineralization at the Ashanti deposit, Obuasi, Ghana. Society of Economic Geologists, Spec. Pub., 9, 65-93.

Artemieva, I, Mooney, W., 2001. Thermal structure and evolution of Precambrian lithosphere : a global study. J. Geophys. Res., 106, 16387-16414.

Barley, M.E., Krapez, B., Groves, D.I., Kerrich, R. 1998. The Late Archean bonanza: metallogenic and environmental consequences of the interaction between mantle plumes, lithospheric tectonics and global cyclicity. Precambrian Res., 91, 65-90.

Beck, A., Mustonen, E. 1972. Preliminary heat flow data from Ghana. Nature, 235, 172174.

Bickle, M. 1986. Global thermal histories. Nature, 319, 13-14.

Blenkinsop, T., Mumm, A.S., Kumi, R., Sangmor, S. 1994. Structural geology of the Ashanti mine. Geologisches Jahrbuch, v. D100, p. 131-153.

Boher, M., Abouchami, W., Michard, A., Albarede, F., Arndt, N.T. 1992. Crustal growth in west Africa at 2.1 Ga. J. Geophys. Res., 97, 345-369 
Bonneville, A., Capolsini, P. 1999. THERMIC: a 2-D finite-element tool to solve conductive and advective heat transfer problems in Earth sciences. Computers and Geosciences, 25, 1137-1148.

Burov, E., Guillou-Frottier, L. 2005. The plume head-continental lithosphere interaction using a tectonically realistic formulation for the lithosphere. Geophys. J. Int., 161, 469-490.

Clauser, C., Huenges, E. 1995. Thermal conductivity of rocks and minerals. In: Ahrens, T.J. (ed) Rock Physics and Phase Relations: A Handbook of Physical Constants. AGU, Washington, D.C., AGU Ref. Shelf, vol 3, pp 105-126.

Davis, D.W., Hirdes, W., Schaltegger, U., Nunoo, E.A. 1994. U-Pb age constraints on deposition and provenance of Birimian and gold bearing Tarkwaian sediments in Ghana, West Africa. Precambrian Res., 67, 89-1997.

De Boorder, H., Spakman, W., White, S.H., Wortel, M.J.R. 1998. Late Cenozoic mineralization, orogenic collapse and slab detachment in the European Alpine Belt. Earth Planet. Sci. Lett., 164, 569-575.

Demongodin, L., Pinoteau, B., Vasseur, G. and Gable, R. 1991. Thermal conductivity and well logs : a case study in the Paris basin. Geophys. J. Int., 105, 675-691.

England, P.C., Bickle, M. 1984. Continental thermal and tectonic regimes during the Archean. J. Geol., 92, 353-367.

Feybesse, J.-L., Milesi, J.-P., 1994. The Archaean/Proterozoic contact zone in West Africa: a mountain belt of décollement thrusting and folding on a continental margin related to 2.1 Ga convergence of Archaean cratons? Precambrian Res., 69, p.199-227.

Feybesse, J.-L., Billa, M., Milesi, J.-P., Lerouge, C., Le Goff, E. 2000. Relationships between metamorphism-deformation-plutonism in the Archean-Paleoproterozoic 
contact zone of West Africa. $31^{\text {st }}$ International Geological Congress, Rio, CD-ROM Abstract.

Gallagher, K., Ramsdale, M., Lonergan, L., Morrow, D. 1997. The role of thermal conductivity measurements in modelling thermal histories in sedimentary basins. Mar. Petrol. Geol., 14, 201-214.

Goldfarb, R., Groves, D., and Gardoll, S., 2001. Orogenic gold and geologic time : a global synthesis. Ore Geol. Rev., 18, 1-75.

Groves, D.I., Condie, K.C., Goldfarb, R.J., Hronsky, J.M.A., Vielreicher, R.M., 2005. Secular changes in global tectonic processes and their influence on the temporal distribution of gold-bearing mineral deposits. Econ. Geol., 100, 203-224.

Guillou, L., Mareschal, J.-C., Jaupart, C., Gariépy, C., Bienfait, G., and Lapointe, R., 1994. Heat flow, gravity and structure of the Abitibi belt, Superior Province, Canada : implications for mantle heat flow. Earth Planet. Sci. Lett., 122, 103-123.

Guillou, L., Jaupart, C., 1995. On the effect of continents on mantle convection. J. Geophys. Res., 100, 24217-24238.

Harcouët V., Guillou-Frottier, L., Bonneville, A., Feybesse, J.-L. 2005. Pre-mineralization thermal evolution of the Paleoproterozoic gold-rich Ashanti belt, Ghana, in Mineral Deposits and Earth Evolution, McDonald et al. (eds.), Geological Society, London, Spec.Pub., 248, 103-118.

Hirdes, W., Davis, D.W., Eisenlohr, B. 1992. Reassesment of Proterozoic Granitoid ages in Ghana on the basis of U/Pb zircon and monazite dating. Precambrian Res., 56, 89-96.

Hirdes, W., Davis, D.W., Lüdtke, G., Konan, G. 1996. Two generations of Birimian (Paleoproterozoic) volcanic belts in northeastern Côte d'Ivoire (West Africa): consequences for the 'Birimian controversy'. Precambrian Res., 80, 173-191. 
Isley, A.E., Abbott, D.H. 1999. Plume-related mafic volcanism and the deposition of banded iron formation. J. Geophys. Res., 104, 15461-15477.

Jaupart, C., Mareschal, J.-C., Guillou-Frottier, L., and Davaille, A., 1998. Heat flow and thickness of the lithosphere in the Canadian Shield. J. Geophys. Res., 103, 1526915286.

Jaupart, C., Mareschal, J.-C. 1999. The thermal structure and thickness of continental roots. Lithos, 48, 93-114.

John, T., Klemd, R., Hirdes, W., Loh, G. 1999. The metamorphic evolution of the Paleoproterozoic (Birimian) volcanic Ashanti belt (Ghana, West Africa). Precambrian Res., 98, 11-30.

Junner, N. 1940. Geology of the Gold Coast and Wester Togoland. Geol. Survey Bulletin, 13.

Kappelmayer, O., Haenel, R. 1974. Geothermics with special reference to application. Gebruder Borntraeger, Berlin/Stuttgart..

Kesse, G. 1985. The mineral and rocks resources of Ghana. A.A. Balkema, Rotterdam, Boston, 609pp.

Kleinschrot, D., Klemd, R., Bröcker, M., Okrusch, M., Schmidt, K. 1993. The Nsuta manganese deposit, Ghana: geological setting, ore-forming process and metamorphic evolution. Z. Angew. Geol., 39, 48-50.

Klemd, R., Hirdes, W., Olesch, M., Oberthür, T. 1993. Fluid inclusions in quartz-pebbles of the gold-bearing Tarkwaian conglomerates of Ghana as guides to their provenance area. Mineral. Deposita, 28, 334-343.

Klemd, R., Hünken, U., Olesch, M. 2002. Metamorphism of the country rocks hosting goldsulfide-bearing quartz veins in the Paleoproterozoic southern Kibi-Winneba belt (SEGhana). J. Afr. Earth Sci 35, 199-211. 
Kukkonen, I.T. 1998. Temperature and heat flow density in a thick cratonic lithosphere: the sveka transect, Central Fennoscandian shield. J. Geodyn., 26, 111-136.

Kukkonen, I.T., Peltonen, P. 1999. Xenolith-controlled geotherm for the central Fennoscandian Shield: implications for lithosphere-astenosphere relations. Tectonophysics, 304, 301-315.

Ledru, P., Johan, V., Milesi, J.-P., Tegyey, M. 1994. Markers of the last stages of the Palaeoproterozoic collision: evidence fr a 2 Ga continent involving circum-South Atlantic provinces. Precambrian Res., 69, 169-191.

Lenardic, A., Kaula, W. M., 2000. Mantle dynamics and the heat flow into the Earth's continents. Nature 378, 709-711.

Lenardic, A., Guillou-Frottier, L., Mareschal, J.-C., Jaupart, C., Moresi, L.-N., Kaula, W.M., 2000. What the mantle sees : the effects of continents on mantle heat flow, in M. Richards et al. (eds). The history and dynamics of global plate motions, Geophysical Monograph 121, AGU, pp 95-112.

Leube, A., Hirdes, W., 1986. The Birimian Supergroup of Ghana: depositional environment, structural development and conceptual model of an Early Proterozoic suite. Hannover, Federal Ministry for Economic Cooperation, 259 p.

Leube, A., Hirdes, W., Mauer, R., Kesse, G.O., 1990. The early Proterozoic Birimian Supergroup of Ghana and some aspects of its associated gold mineralization. Precamb Res. 46, 139-165.

Lucazeau, F., Lesquer, A., Vasseur, G. 1991. Trends of hest flow density from West Africa. In R.L. Cermak V. 5Ed.), Terrestrial heat flow and the lithosphere, Heidelberg New York, pp. 417-425

Lucazeau, F., Brigaud, F., Bouroullec, J.-L. 2004. High-resolution heat-flow density in the lower Congo basin. Geochim. Geophys. Geosyst., 5 (2), 115-134. 
Milesi, J.-P., Feybesse, J.L., Ledru, P., Dommanget, A., Ouedraogo, M.F., Marcoux, E., Prost, A., Vinchon, C., Sylvain, J.P., Johan, V., Tegyey, M., Clavez, J.Y., Lagny, Ph. 1989. Mineralisations aurifères de l'Afrique de l'ouest, leurs relations avec l'évolution litho-structurale au Paleoproterozoïque inférieur. Chron. Rech. Min., 497, 3-98.

Milesi, J.-P., Ledru, P., Ankrah, P., Johan, V., Marcoux, E., Vinchon, C. 1991. The metallogenic relationship between Birimian and tarkwaian gold deposits in Ghana. Mineral. Deposita, 26, 228-238.

Milesi, J-P., Feybesse, J-L., Pinna, P., Deschamps, Y., Kampuzu, H., Muhongo, S., Lescuyer, J-L., Le Goff, E., Delor, C., Billa, M., Ralay, F., Heinry, C. 2004. Géologie et principaux gisements d'Afrique - carte et SIG à $1 / 10000000,20^{\text {th }}$ Colloquim of African Geology, Orléans, France, 02-07 June, 2004.

Nisbet, E.G., Fowler, C.M.R. 1982a. The thermal background to metamorphism- 1. Simple one-dimensional conductive models. Geosciences Canada 9, 3, 161-164.

Nisbet, E.G., Fowler, C.M.R. 1982b. The thermal background to metamorphism- II. Simple two-dimensional conductive models. Geosciences Canada 9, 4, 208-214.

Oberthür, T., Weiser, T., Amanor, J.A., Chryssoulis, S.L. 1997. Mineralogical siting and distribution of gold in quartz veins and sulfide ores of the Ashanti mine and other deposits in the Ashanti belt of Ghana: genetic implications. Mineral. Deposita, 32, 215.

Oberthür, T., Vetter, U., Davis, D.W., Amanor, J.A. 1998. Age constraints on the gold mineralization and Paleoproterozoic crustal evolution in the Ashanti belt of southern Ghana. Precambrian Res., 89, 129-143.

Opare-Addo, E., John, B.E., Browing, P. 1993a. Field and geochronologic (U-Pb) constraints on the age and generation of granitoids and migmatites in southern Ghana, AGU Spring meeting, Baltimore, EOS Trans. Abst. Suppl., 74, 16, 301. 
Opare-Addo, E., Browing, P., John, B.E. 1993b. Pressure-Temperature constraints on the evolution of an early Proterozoic plutonic suite in southern Ghana, West Africa. J. Afr. Earth Sci 17, 13-22.

Pigois, J.P., Groves, D.I., Fletcher, I.R., McNaughton, N.J., Snee, L.W. 2003. Age constraints on Tarkwaian paleoplacer and lode-gold formation in the Tarkwa Damang district, SW Ghana. Mineral. Deposita, 38, 695-714.

Pirajno, F. 2001. Ore deposits and mantle plumes. Kluwer Academic Publishers, Dordrecht, $576 \mathrm{pp}$.

Ranalli, G. 2000. Rheology of the crust and its role in tectonic reactivation. J. Geodyn., 30, $3-15$.

Richter, F.M. 1985. Models for the Archean thermal regime. Earth Planet. Sci. Lett., 73, $350-360$.

Rolandone, F., Jaupart, C., Mareschal, J.-C., Gariépy, C., Bienfait, G., Carbonne, C., Lapointe, R. 2002. Surface heat flow, crustal temperatures and mantle heat flow in the Proterozoic Trans-Hudson Orogen, Canadian shield. J. Geophys. Res., 107, B12, 2341.

Russel, J.K., Kopylova, M.G. 1999. A steady-state conductive geotherm for the north central Slave, Canada : inversion of petrological data from the Jericho kimberlite pipe. J. Geophys. Res., 104, 7089-7101.

Schmidt Mumm, A., Oberthür, T., Vetter, U., Blenkinsop, T.G. 1997. High CO2 content of fluid inclusions in gold mineralisations in the Ashanti belt, Ghana: a new category of ore forming fluids? Mineral. Deposita, 32, 107-118.

Seipold, U. 1998. Temperature dependence of thermal transport properties of crystalline rocks- a general law. Tectonophysics, 291, 161-171. 
Serban, D.Z., Nielsen, S.B., Demetrescu, C. 2001. Transsylvanian heat flow in presence of topography, paleoclimate, and groundwater flow. Tectonophysics, 335, 331-344.

Sillitoe, R.H., 1972. A plate tectonic model for the origin of porphyry copper deposits. Econ. Geol., 67, 184-197.

Smithies, R.H., Champion, D.C., Cassidy, K.F., 2003. Formation of the Earth's early Archean continental crust. Precambrian Res., 127, 89-101.

Starin, L., Yuen, D.A., Bergeron, S.Y. 2000. Thermal evolution of sedimentary basin formation with variable thermal conductivity. Geophy. Res. Lett., 27, 265-268.

Sylvester, P.J., Attoh, K. 1992. Lithostratigraphy and composition of 2.1 Ga greenstone belts of the West African craton and their bearing on crustal evolution and the Archean-Proterozoic boundary. J. Geol., 100, 377-393.

Taylor, P.N., Moorbath, S., Leube, A. Hirdes, W. 1992. Early Proterozoic crustal evolution in the Birimian of Ghana: constraints from geochronology and isotope geochemistry. Precambrian Res., 56, 97-111.

Trubitsyn, V.P., Mooney, W.D., Abbott, D.H., 2003. Cold cratonic roots and thermal blankets : how continents affect mantle convection. Int. Geol. Rev., 45, 479-496.

Turcotte, D., Schubert, G. 2002. Geodynamics : Applications of Continuum Physics to Geological Problems, 2nd ed., Cambridge Univ. Press, New York, 456 pp.

Vosteen, A., Schellschmidt, R. 2003. Influence of temperature on thermal conductivity, thermal capacity and thermal diffusivity for different types of rock. Phys. Chem. Earth, 28, 299-509.

Watson, J.V. 1978. Precambrian thermal regimes. Phil. Trans. R. Soc. Lond. A., 288, 431440. 
Wyllie, P.J. 1977. Crustal anatexis : an experimental review, in : D.H. Green (Ed.), Experimental Petrology Related to Extreme Metamorphism. Tectonophysics, 43, 4171.

Yao, Y., Murphy, P.J., Robb, L.J. 2001. Fluid characteristics of granitoid-hosted gold deposits in the Birimian Terrane of Ghana: a fluid inclusion microthermometric and Raman spectroscopic study. Econ. Geol., 96, 1611-1643.

Zoth, G., Hänel, R. 1988. Appendix. In L. R. R. Hänel and L. Stegena (Eds.), Handbook of Terrestrial Heat Flow Density Determination. Kluwer, Dordrecht, pp 449-468. 


\section{Figure captions}

Figure 1: (a) Simplified geological map of south Ghana. Main lithological units are given with the age of their emplacement (Opare-Addo et al., 1993b; Davis et al., 1994; Oberthür et al., 1998; Feybesse et al., 2000; Pigois et al., 2003). Syn-D1 and syn-D2 thrusting events are illustrated by dotted line. Locations of the main gold deposits are indicated by black and grey dots. Cross section A-A' is shown in Figure 2. (b) Time chart illustrating the emplacement of the main rock units observed in the field (see map), the succession of the main tectonic phases related to the Eburnean orogeny and the tectonic events that were modelled in this study.

Figure 2: Geodynamical evolution model for the Ashanti and surrounding belts, between 2130 and $2086 \mathrm{Ma}$ assuming the presence of a continental basement. a) Initial stage at 2130 (pre-D1) accounts for thermobarometric data in the monzogranites. b) At 2105 Ma, the central unit has been overthrusted during D1 by those from the east, implying the burial of sediments and metamorphism in the greenschist facies, while the Ashanti belt was recovered by sediments and barren conglomerates (Kawere). c) result after a phase of erosion and deposition of Tarkawian conglomerates of the Banket series. d) Syn-D2 thrusting events cause the burial of the western part of the Ashanti belt. e) Final stage after exhumation.

Figure 3: Thermal conductivity of sedimentary rocks as a function of: temperature (adapted from Vosteen and Schellschmidt, 2003), compaction (adapted from Serban et al., 2001), both temperature and compaction (this study). As a comparison a typical thermal conductivity for fresh sediments is shown (constant, $1.8 \mathrm{~W} \cdot \mathrm{m}^{-1} \cdot \mathrm{K}^{-1}$ ). Equations (2b) and (6) from the text are used to calculate $\lambda(\mathrm{T})$ and $\lambda(\mathrm{T}, \mathrm{z})$ 
respectively. For the calculations a geothermal gradient of $30{ }^{\circ} \mathrm{C} / \mathrm{km}$ is used, $\lambda\left(25^{\circ} \mathrm{C}\right)$ is $2.9 \mathrm{~W} \cdot \mathrm{m}^{-1} \cdot \mathrm{K}^{-1}$ and a surface porosity of $50 \%$ is assumed.

Figure 4: a) Maximum temperature at the base of the monzogranitic unit (at $23 \mathrm{~km}$ depth) as a function of mantle heat flow. Thermobarometric data suggesting that the temperature ranged between 650 and $800{ }^{\circ} \mathrm{C}$ at this depth are used to infer the minimum mantle heat flow value $\left.\left(26 \mathrm{~mW} \cdot \mathrm{m}^{-2}\right) . \mathrm{b}\right)$ Maximum temperature at the base of the crust as a function of the imposed mantle heat flow at the base of the model. This temperature is assumed to be less than $900{ }^{\circ} \mathrm{C}$, which allows deduction of the maximum mantle heat flow value $\left(31 \mathrm{~mW} \cdot \mathrm{m}^{-2}\right)$. c) Temperature field at the initial stage calculated with a mantle heat flow value of $29 \mathrm{~mW} \cdot \mathrm{m}^{-2}$ (in the continental basement case). This value allows the conditions for partial melting in the monzogranites to be reached and a temperature at the base of the crust to be lower than $900^{\circ} \mathrm{C}$. Letters 'S', 'G', 'M' and 'B' refer to sediments, greenstone belts, monzogranitic unit and basement respectively.

Figure 5: Computed P-T paths (dashed and solid arrows) based on the predictions of the numerical modelling compared with thermobarometric data (shaded zone based on the data given in Table 2). a) P-T path corresponding to the burial of sediments from the Birim basin, after D1 thrusting. b) P-T paths followed by Tarkwaian sediments (dashed arrow) and greenstones from the Ashanti belt (solid arrow), during the exhumation phase, after the D2 thrusting event.

Figure 6: a) Initial temperature field calculated in the case of an oceanic basement with a mantle heat flow value of $37 \mathrm{~mW} \cdot \mathrm{m}^{-2}$. With this value the conditions of partial melting in the monzogranites are reached (encircled zone) and the temperature at the base of the crust is still lower than $900{ }^{\circ} \mathrm{C}$ below the eastern units. P-T paths followed by rocks of the Birim basin (dashed arrow) during D1 tectonism are shown in a) and 
P-T paths from Tarkwaian sediments (dashed arrow) and greenstones (solid arrow) after D2 thrusting are illustrated in c). Computed data do not fit thermobarometric estimations for the later. See caption of figure 4 for the explanation of 'S','G','M' and 'B'.

Figure 7: Comparison of retrograde P-T paths followed by sediments from the Birim basin when thermal conductivity is constant for all types of rock and when it is a function of depth and temperature (dotted line). The mantle heat flow values $\left(\mathrm{Q}_{\mathrm{m}}\right), 55$ and 29 $\mathrm{mW} \cdot \mathrm{m}^{-2}$ respectively, are the solutions inferred from the thermal models which fit P-T data reported in Table 1. The maximum temperatures are reached with a time lag of about $1 \mathrm{Ma}$ and are lower when thermal conductivity is not constant (see text for explanation). 
Period P-T conditions Area

\begin{tabular}{|c|c|c|}
\hline Pre-D1 & $6 \mathrm{kbar}, 650-800^{\circ} \mathrm{C}$ & Monzogranitic unit \\
\hline \multirow[t]{5}{*}{ D1 } & greenschist facies & Sediments of the Birim \\
\hline & & basin (regional) \\
\hline & upper-greenschist & Sediments at the contact \\
\hline & to mid-amphibolite & of granitoids \\
\hline & facies & \\
\hline \multirow[t]{4}{*}{ D2 } & upper-greenschist to & \\
\hline & mid-amphibolite facies & \\
\hline & $3.5-5 \mathrm{kbar}, 450-600^{\circ} \mathrm{C}$ & Tarkwaian conglomerates \\
\hline & 4-6 kbar, $490-650{ }^{\circ} \mathrm{C}$ & Ashanti greenstone belt \\
\hline
\end{tabular}

Table 1: Pressure-Temperature estimations associated to the different tectonic phases. PreD1 data: Feybesse (comm. pers. , 2004) and Harcouët et al. (2005); D1 data: Feybesse and Milesi (1994); Opare-Addo et al. (1993a,b); Feybesse et al. (2000) and Harcouet et al. 2005; and D2 data: Kleinschrot et al. (1993); John et al. (1999); Klemd et al. (2002); Pigois et al (2003); Milesi et al., (1989) and Ledru et al., (1994). 


\begin{tabular}{lllll} 
Rock type & Mean & s.d. & Mean & s.d. \\
& thermal conductivity & $\left(\mathrm{W} \cdot \mathrm{m}^{-1} \cdot \mathrm{K}^{-1}\right)$ & heat-production rate & $\left(\mu \mathrm{W} . \mathrm{m}^{-3}\right)$ \\
& & & at $2100 \mathrm{Ma}$ & \\
& $\left(\mathrm{W} \cdot \mathrm{m}^{-1} \cdot \mathrm{K}^{-1}\right)$ & & $\left(\mu \mathrm{W} \cdot \mathrm{m}^{-3}\right)$ & \\
\hline Basement & $2.60^{*}$ & & & 1.28 \\
Greenstones & 2.93 & 0.74 & 0.69 & 0.45 \\
Meta-sediments & 2.89 & 0.90 & 1.38 & 0.75 \\
Monzogranites & 3.10 & 0.59 & 1.88 & 0.82 \\
Tarkwaian & 3.12 & 0.62 & 1.85 & 1.62 \\
conglomerates & & & &
\end{tabular}

Table 2: Main lithological units with associated mean thermal properties and standard deviations (s.d.). Thermal properties are from this study except $\left(^{*}\right)$ from Turcotte and Schubert (2002). 
a)
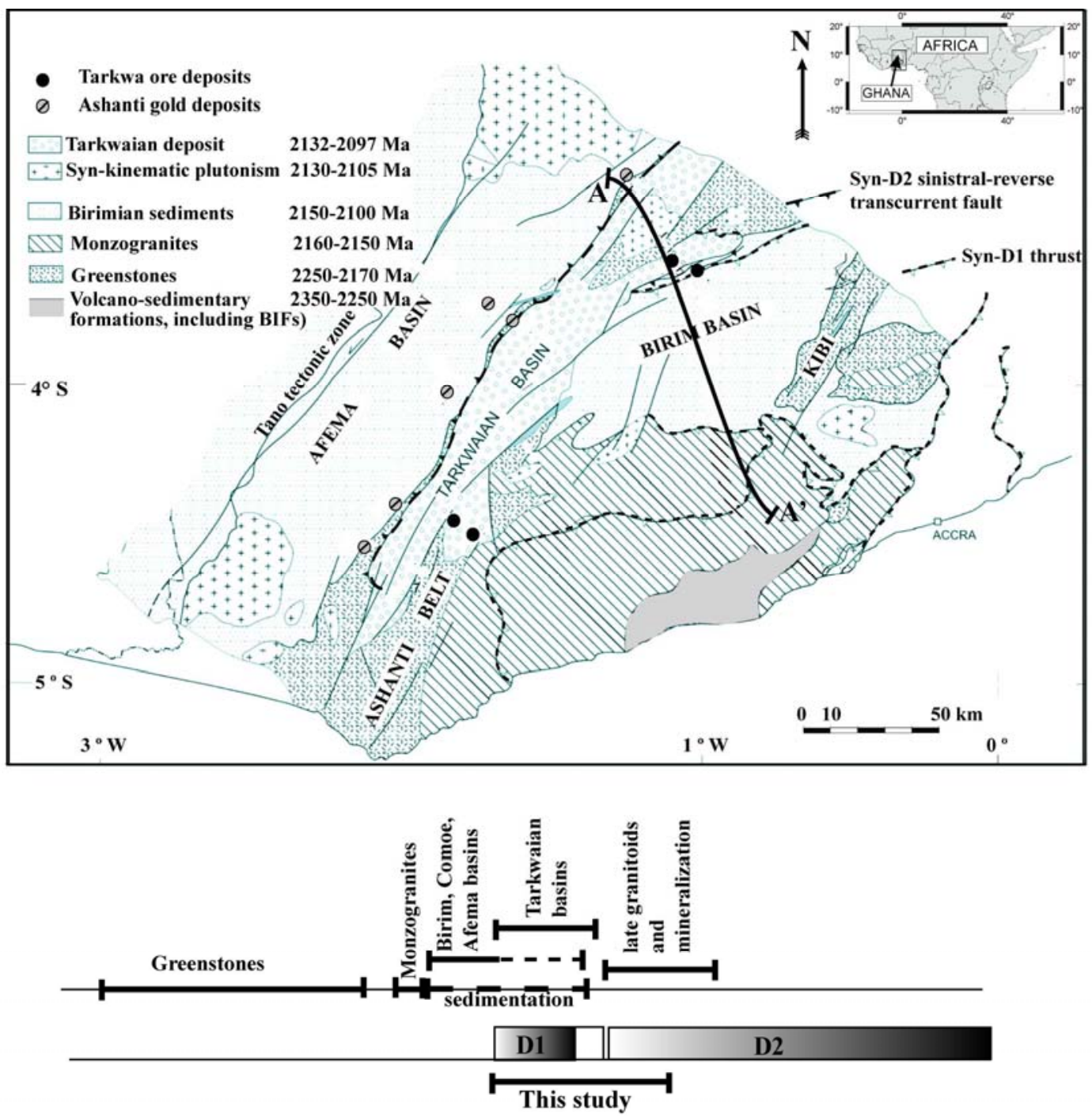

b)

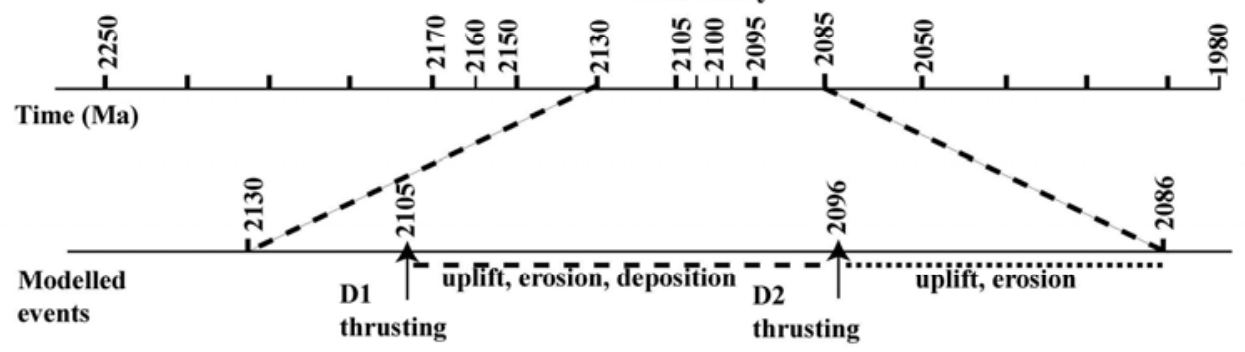

Figure 1 
a)

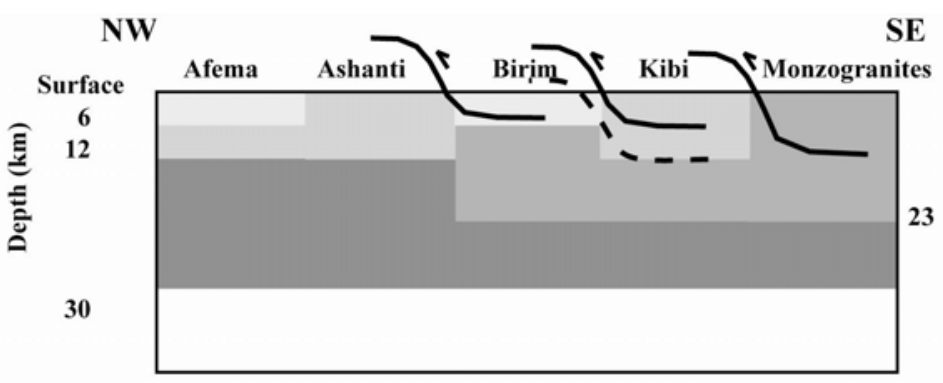

After instantaneous thrusting, $\mathrm{t} \sim 2105 \mathrm{Ma}$

b)

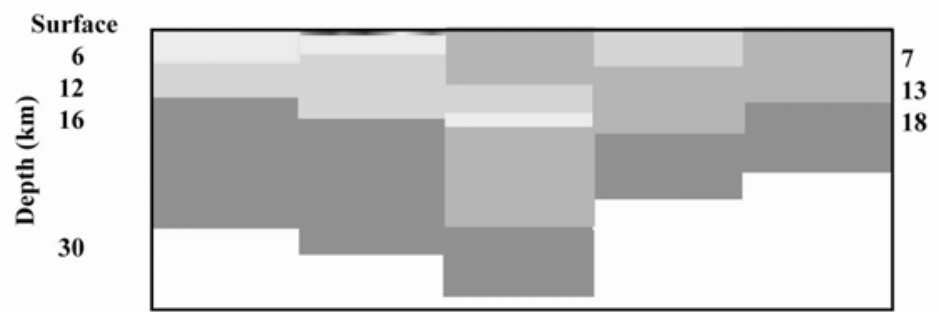

After uplift, erosion and deposition, $\mathrm{t} \sim 2097 \mathrm{Ma}$

c)

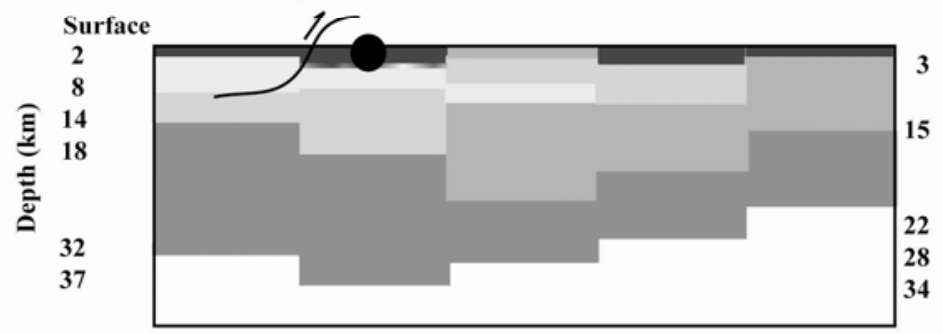

d)

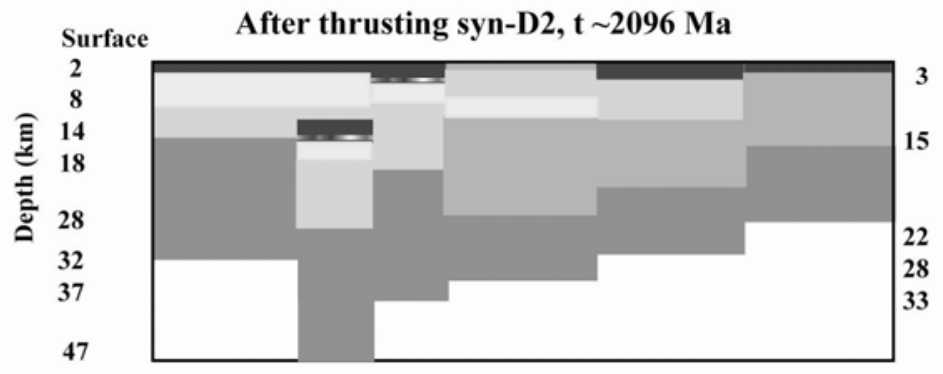

After uplift and erosion, $\mathrm{t} \sim 2086 \mathrm{Ma}$

e)

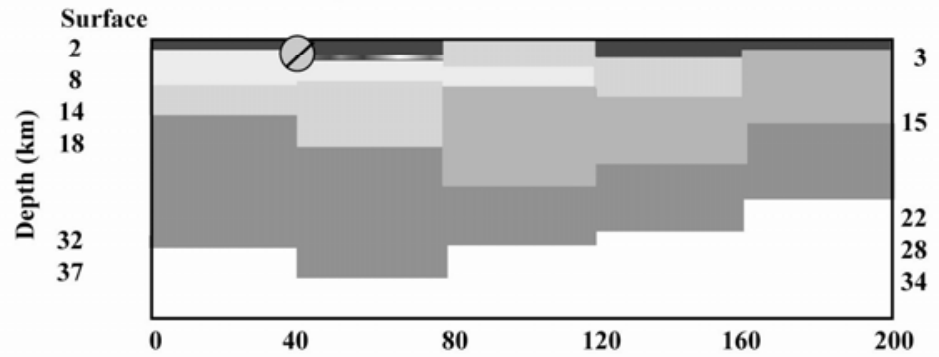

Kawere conglomerates

Tarkwaian conglomerates

Monzogranites

Birimian sediments

Greenstones

Archean basement

Mantle

- - - Supposed source of gold \& quartz pebbles of Tarkwa deposits

Emplacement of Tarkwa ore deposits

Future emplacement of Ashanti gold deposits

\section{Figure 2}




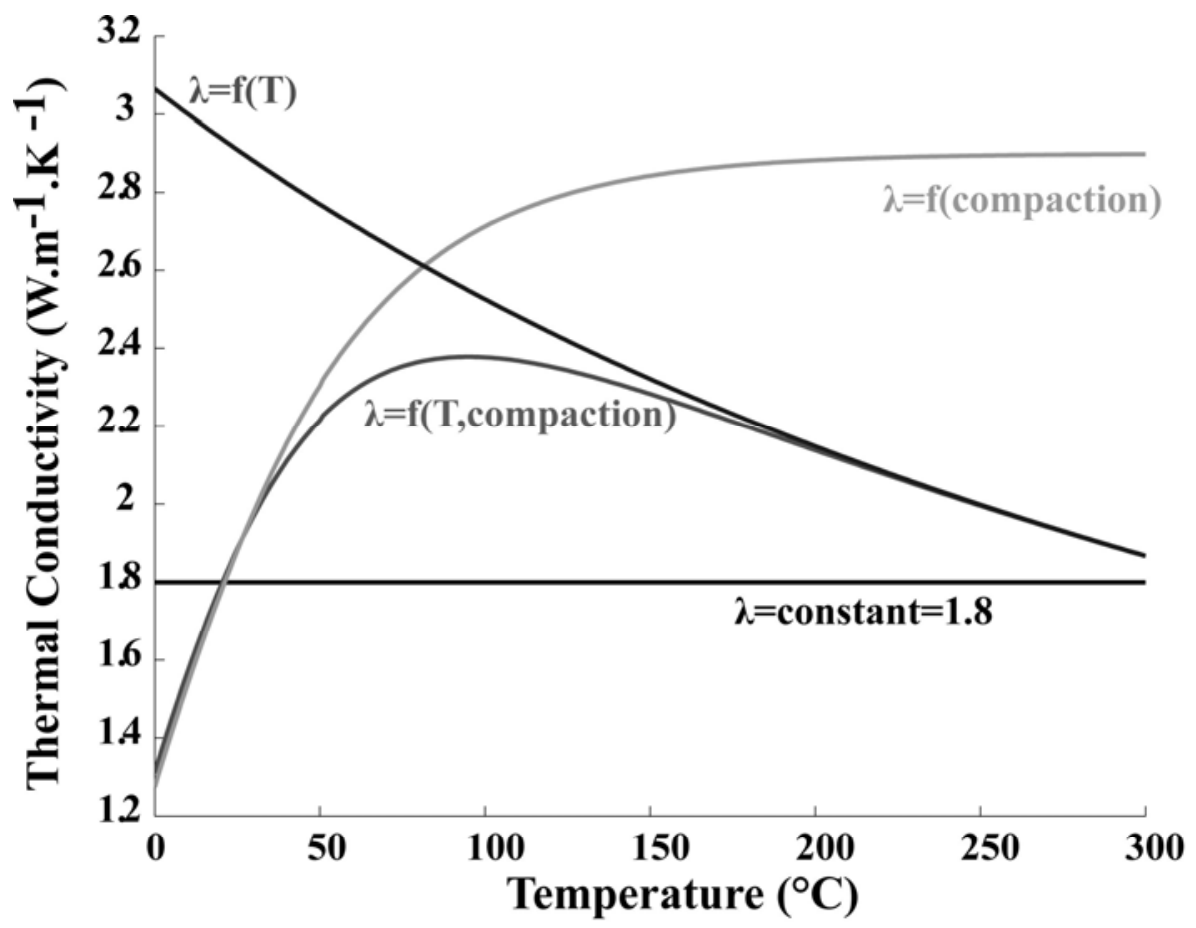

Figure 3 


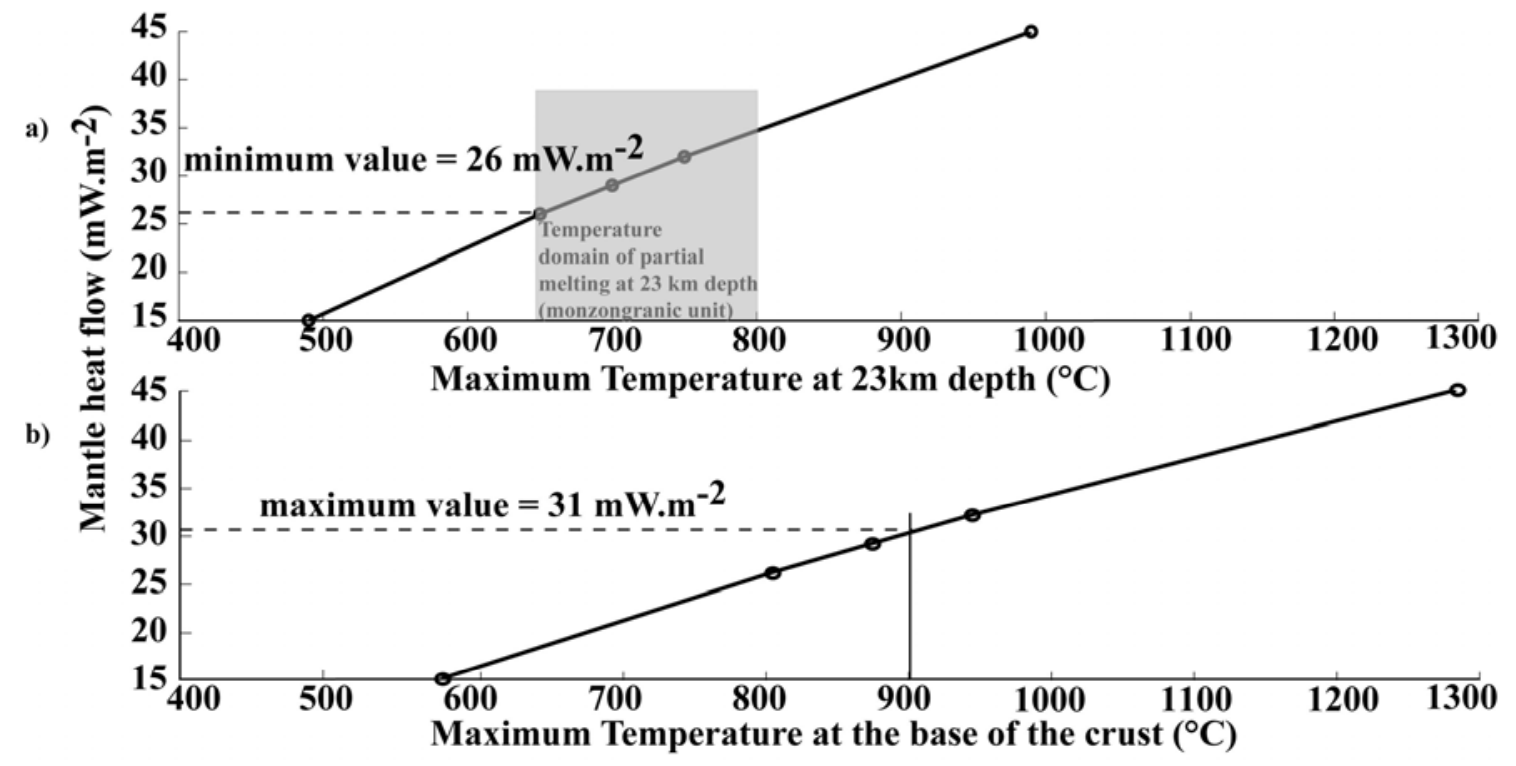

Initial stage t: $2130 \mathrm{Ma}$

c)

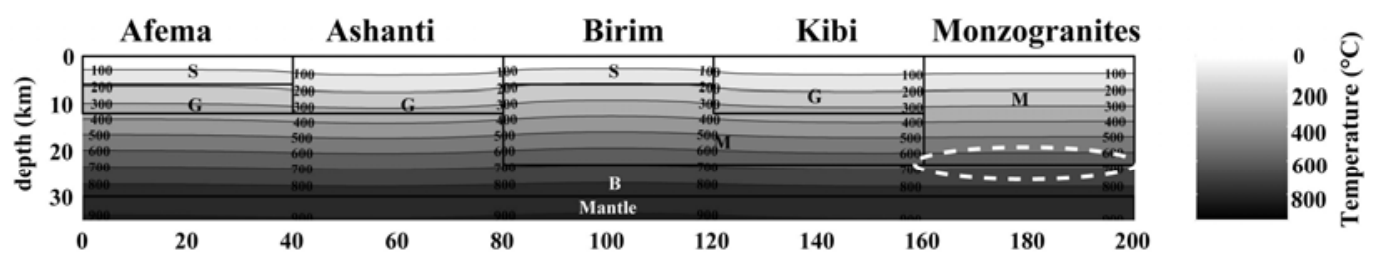

Figure 4 

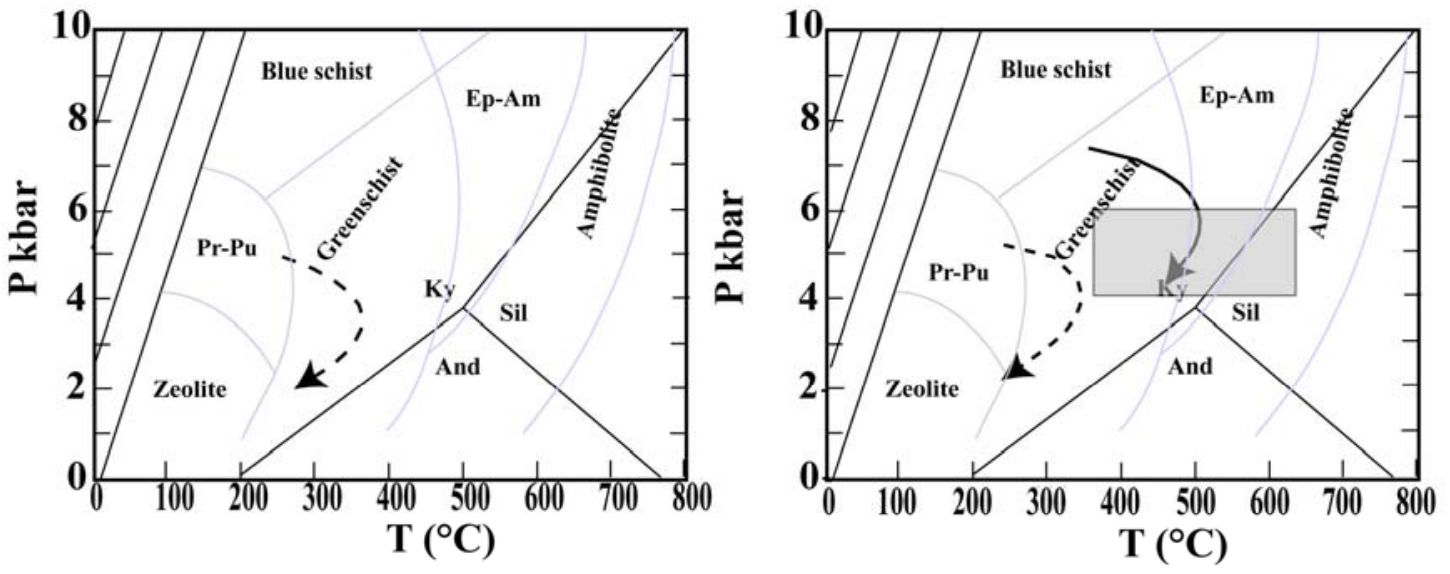

Figure 5 
Initial stage t: $2130 \mathrm{Ma}$
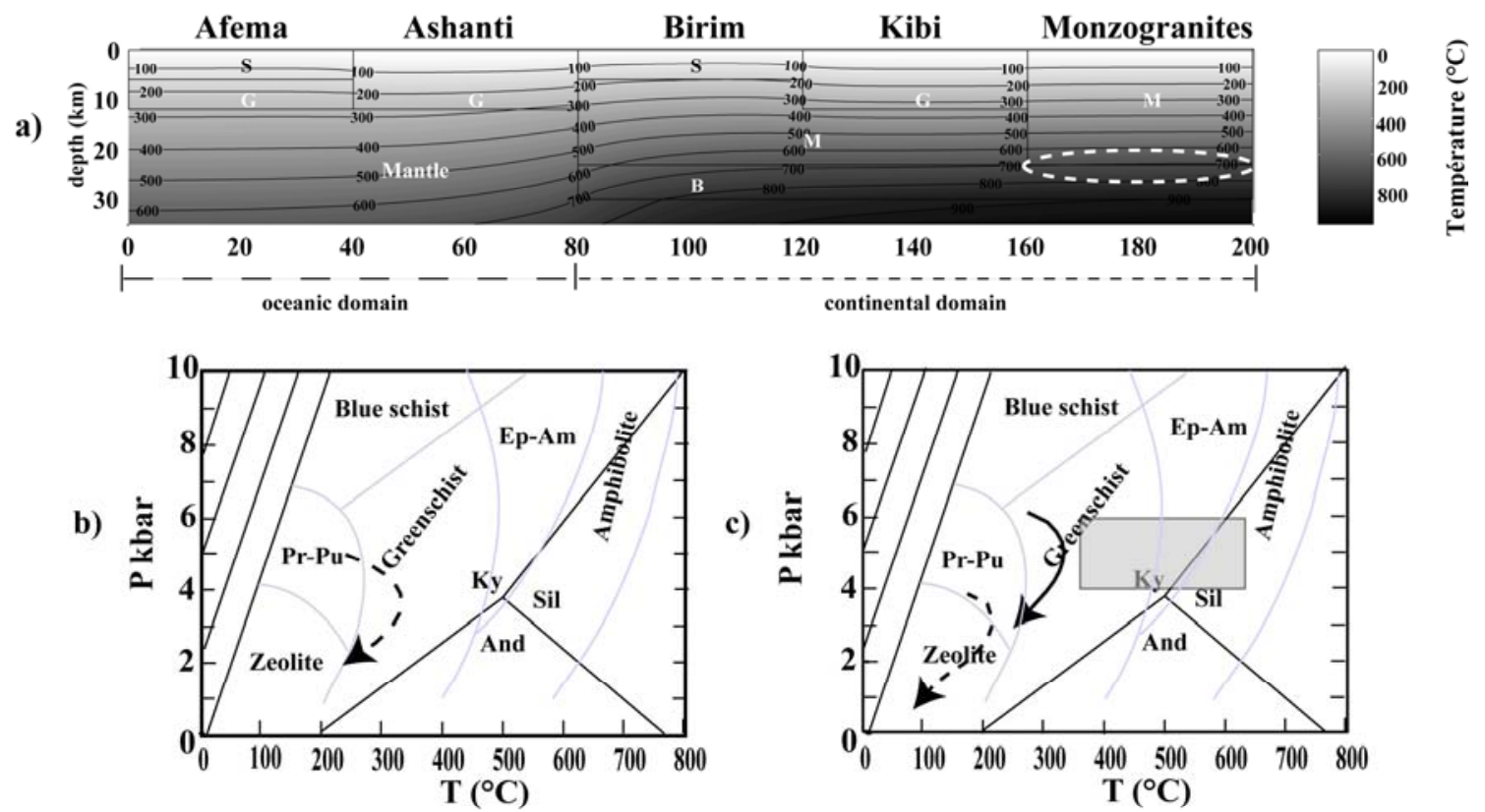

Figure 6 


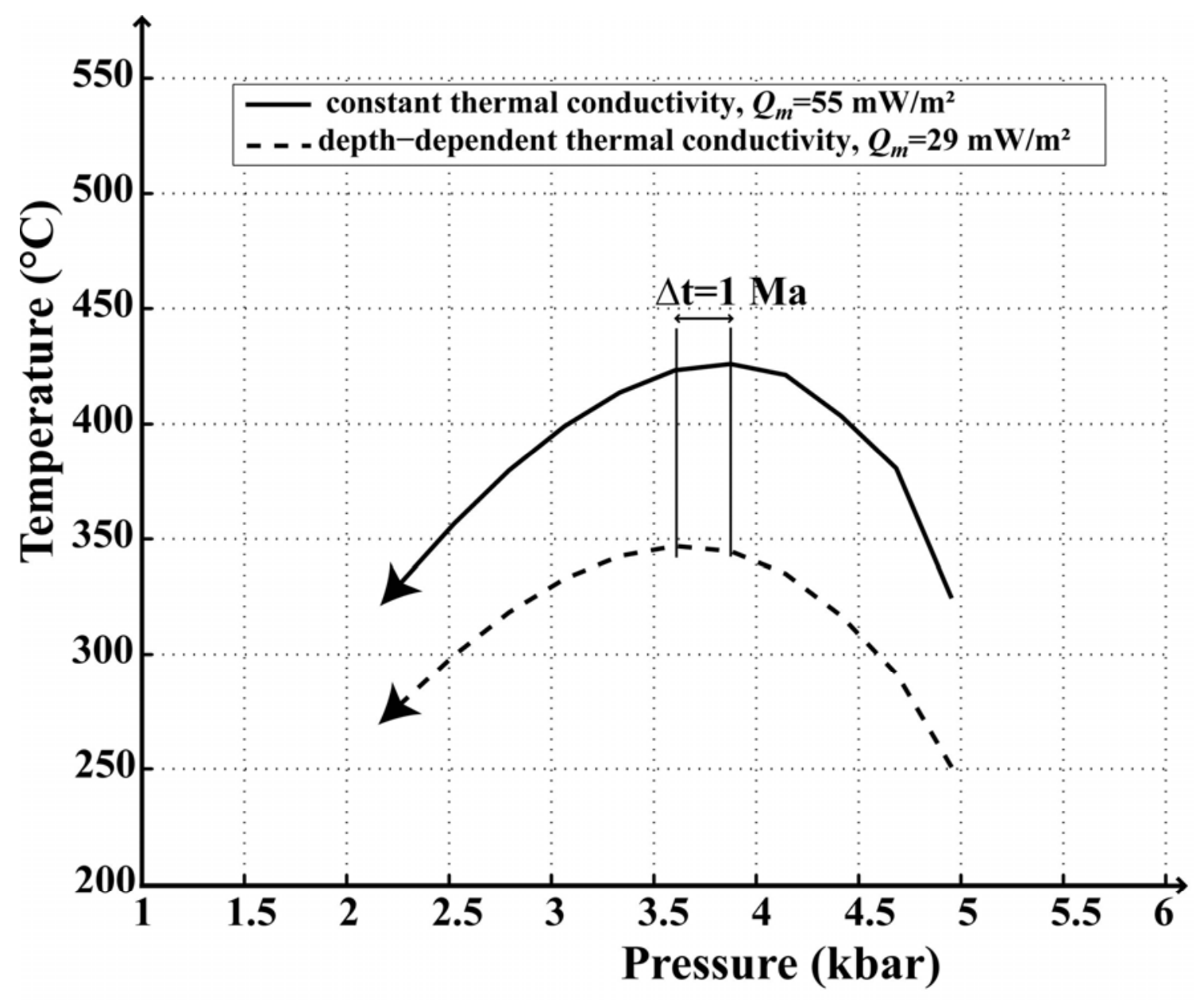

Figure 7 